\title{
A Comparison of Pollution, Environmental Hazards, Sedimentology, and Geochemistry, in Five Economic Harbors Along the Egyptian Coast of Mediterranean Sea
}

Manal El-Sadaawy ( $\square$ manal_dn@yahoo.com)

National Institute of Oceanography and Fisheries Alexandria Branch: National Institute of Oceanography and Fisheries Mediterranean Sea Branch https://orcid.org/0000-0002-4935-6222

\section{Ghada F. El-Said}

National Institute of oceanography and Fisheries

Mona Khalil

National Institute of Oceanography and Fisheries

\section{Fadia A.M. Morsy}

National Institute of oceanography and Fisheries

Suzan E.O. Draz

National Institute of oceanography and Fisheries

\section{Research Article}

Keywords: Sediment characterization, Heavy metals, Pollution and ecological risks, Human health hazard, Five harbors, Egypt

Posted Date: January 7th, 2022

DOI: https://doi.org/10.21203/rs.3.rs-1097962/v1

License: () (1) This work is licensed under a Creative Commons Attribution 4.0 International License. Read Full License 


\section{Abstract}

Heavy metal pollution and its environmental and human risks have become one of the most important global environmental problems. In the current study, the potential heavy metals ecological risks and their pollution status were assessed in five important harbors (Sidi Krir, Dekhila, Western, Damietta, and Port Said) along the Egyptian coast of the Mediterranean Sea. Twenty-six sediment samples were collected from five harbors, where eight heavy metals (Fe, Mn, Zn, Cu, $\mathrm{Ni}, \mathrm{Cr}, \mathrm{Pb}$ and $\mathrm{Cd}$ ) were identified as well as their texture and geochemistry. To gain deeper insights into the human and ecological hazards of the heavy metals, thirteen ecological indices, sediment quality guidelines and multivariate analysis as well as two pathways of exposures to non- carcinogenic and carcinogenic risk of heavy metals for children and adults were evaluated. The data shown that Sidi Kriri harbor recorded the lowest values for heavy metals, for $\mathrm{Cu}$, while Western Harbor had the highest average for Zn Multivariate analysis revealed the contribution of heavy metals to sediment contamination and the geochemical characteristics as well as nearby sources of pollution. Geo-accumulation index, Contamination factor, Toxic units, sum of toxic units, sediment modified hazard quotient, and sediment hazard quotients reflected the significant contribution of Cd to sediments along all harbors. Noncarcinogenic hazard risk index $(H I)$ values along the harbors gave the order: Western $>$ Port Said $>$ Damietta $>$ Dekhila> Sidi Krir. Also, TLCR values for children and adults indicated the irregularly high abundance of heavy metals in harbor sediments that may cause adverse public health effects.

\section{Introduction}

Heavy metals are the main man-made pollutants in the global coastal and marine environment. Due to potential toxicity, multiple sources, and cumulative pollution, pollution of the coastal environment is one of the environmental issues that arouse the attention of the scientific community (El Barjy et al. 2020). It was pointed out that more than $99 \%$ of the heavy metals entering the marine water system are stored in the sediment in various ways, that is, the sediment can be used as a large heavy metal storage pool (Shen et al. 2019). Sediment's heavy metals originate from both natural and human sources (Deng et al. 2020). Heavy metals in marine systems can be released into the water column under appropriate parameters and affect the ecosystem. Over time, the further development of human activities has increased the toxicity of heavy metals and integrated them into the food chain by transferring them from sediments to the marine environment. Thus, the accumulation of heavy metals in marine organisms and finally in human consumers has become an issue of concern in modern society as they threaten their health.

Several conventions and international organizations have been established heavy metals-based indices to assess marine sediment pollution, and a variety of methods have been used to evaluate heavy metal pollution and its potential environmental hazards in sediments. These methods include the enrichment factor $(E F)$, contamination factor $\left(C_{F}\right)$, and geoaccumulation index $\left(I_{g e o}\right)$, Enrichment factor $(E F)$, Contamination factor $\left(C_{f}\right)$, degree of contamination $\left(C_{d}\right)$ and pollution load index (PLI) methods. Although these methods cannot provide information about the toxicity of heavy metals, they cannot fully reflect the overall toxicity of heavy metals (Liu et al. 2019). Therefore, a potential ecological risk index (PERI) method was proposed to compensate for this shortcoming, and it has become a popular method for evaluating heavy metal pollution in marine sediments.

The Sediment Quality Guidelines (SQGs) is necessary to detect contaminated sediment hotspots and the potential impact of contaminated sediments on benthic organisms (Enuneku 2018). By comparing the concentration of sediment pollutants with the criteria for quality matching, sediment pollution can be estimated (MacDonald et al. 2000). These guidelines can also help clarify sediment quality.

Two criteria were developed: the low and median range effects (ERL/ERM) and the threshold/probable effect level (TEL/PEL). The low range (ERL or TEL) values were reported as a pollutant contaminant with a relatively low impact on biological communities. Under this concentration, there would be rare adverse effects upon on sediment-dwelling animals. On the other hand, ERM and PEL values represent contaminant concentrations above which adverse effects are likely to occur (MacDonald et al. 1996; Long and MacDonald 1998). These SQGs were developed based on sediment toxicity information collected for freshwater and saltwater sediments throughout the USA and were developed in a manner consistent with the TELs and PELs for freshwater sediments (Smith et al. 1996). Human health risk assessment of potentially toxic heavy metals provides an indication of the risk level due to pollutant exposure, and it is based on the characterization or quantification of the risk level either as carcinogenic or a non-carcinogenic risk (Cherf et al. 2016).

The current research plan was to sample sediments from five harbors, which are named: Sidi Krir Harbor, Dekhila Harbor, Western Harbor, Damietta Harbor, and Port Said Harbor(1) to identify the spatial distributions of some heavy metals in the sediments; (2) to state the metal pollution status using some established guidelines and pollution indices; (3) to follow heavy metals ecotoxicity by different ecological indices; (4) to estimate the impact of heavy metals on human health; (5) to estimate the potential sources of heavy metal contamination by using the multivariate statistical analysis.

\section{Materials And Methods}

\section{Area of study}

Twenty-six sediment samples were tested from Sidi Krir (A), Dekhila (B), Western (C), Damietta (D), and Port Said (E) Harbors located along the Egyptian Mediterranean Sea coast.

Sidi Krir Harbor (A) is located on the west coast of Alexandria City. It is a typical carbonate province with an open coastal environment. It lies between Latitudes $31.05^{\circ}$ and $31.09^{\circ} \mathrm{N}$ and Longitudes $29.58^{\circ}$ and $29.70^{\circ} \mathrm{E}$ (Fig. 1). The near shore seabed is characterized by a relatively gentle slope, while the seabed is steep and the continental shelf is very narrow or missing (Abdel-Halim et al. 2016). The shore is mostly sandy, with a relatively wider beach. There are various activities in the area such as: a power plant that use tar instead of natural gas for a long time, the Arab Petroleum Pipe Company SUMED (Suez, Mediterranean pipeline), and some tourist villages that may dispose of waste directly into the sea without treatment, resulting in serious pollution in the area. 
Dekhila Harbor (B) is located on the western side of El-Mex Bay (Fig. 1). It is a semi-enclosed basin constructed in 1986 for the export of manufactured iron and steel and the import of coal (Heneash 2015). It also plays an important role in the export and import of other goods such as minerals, ores, fertilizers, salts and grain. The surface area of the harbor is about $12.5 \mathrm{~km}^{2}$ and the water depth ranges from 4 to $20 \mathrm{~m}$. The harbor's water is exposed to several sources of wastewaters coming from the El-Mex Bay through El-Umoum drain.

Western Harbor (C) is considered one of the most important and largest harbors in the Mediterranean (Fig. 1). The length of the Western Harbor is $7 \mathrm{~km}$ and the maximum width is $2 \mathrm{~km}$ (Saad et al. 2003). The depth of its water ranges from 5.5 to $14.0 \mathrm{~m}$ and its region is divided into internal and external mouths of 200 acres and 600 acres respectively. It is a shallow and semi-enclosed basin that directly receives variable volumes of drainage from the Nubariya Canal $(\approx$ $9000 \mathrm{~m}^{3}$ /day) and El-Umoum drainage. Due to the prevailing winds the drainage waters of Nubariya Canal and El-Umoum drain enters WH area. The harbor also suffers from intense marine activities, including the import of fertilizers, coal, cement, and export of oil. Harbor (C) is under pressure from various pollutants from different external and internal sources. The external pollution originates from household, industrial and agricultural waste. In addition, a large amount of untreated sewage and industrial waste are also dumped directly into Western Harbor from multiple outlets. The internal pollution originates from different shipping wastes other than discharges generated during the loading and unloading of imported and exported industrial raw materials.

Damietta Harbor (D) is a marine harbor located west of Damietta City on the coast of Nile Delta in Egypt (El-Gharabawy et al. 2011). It was constructed in 1982 for about $10 \mathrm{~km}$ west to Damietta outlet of the Nile River. It is semi-closed water body with an area of about $11.8 \times 10^{6} \mathrm{~m}{ }^{2}$, and it is situated between Latitudes $31.29^{\circ} \mathrm{N}$ and Longitudes $31.45^{\circ} \mathrm{E}$ (Fig. 1). The harbor is mainly affected by loading/unloading operations, municipal and agricultural waste from Damietta Governorate. It is mainly affected by human activities including fishing.

Port Said Harbor (E) is located on the northern entrance of the Suez Canal and is considered one of the most important Egyptian ports. Due to its privileged location at the entrance of the largest international shipping corridor (Suez Canal) and in the middle of the largest commercial shipping line connecting Europe to the east and the largest transit port in the world. Its total area about $3,000,800 \mathrm{~m}^{2}$, with water surface is $1.733 .800 \mathrm{~m}^{2}$ and land surface area is 1.267 .095

$\mathrm{m}^{2}$. It is situated between Latitudes $31.15^{\circ} \mathrm{N}$ and Longitudes $32.18^{\circ} \mathrm{E}$ (Fig. 1). Most of the days of the year and the prevailing winds are moderate to moderate northwesterly winds, with $50 \mathrm{~cm}$ tides. Damietta and Port Said are exposed to agricultural drains contaminated with hazardous industrial wastes, domestic sewage, organic matter, fertilizers and pesticides, in addition to oil pollution from ships and oil terminal (Soliman et al. 2015).

\section{Sampling and elemental analysis}

26 surface sediments samples were taken from A (Sites 1-5), B (Sites 6-10), C (Sites11-16); D (Sites 17-21) and E (Sites 22-29) using Ekman grab sampling tool during winter 2018 (Fig. 1). The collected sediment samples were transported to the National Institute of Oceanography and Fisheries in an ice box. In the laboratory, samples were stored in polypropylene bags and kept in the freezer at $\left(-20^{\circ} \mathrm{C}\right)$ processing and analysis. Each of the frozen sediments were spread separately on glass plates and dried at room temperature. Each of the sediment samples was frozen dried, then grind with a pestle and mortar and sift to pass a $63 \mu \mathrm{m}$ mesh sieve. A portion of each sediment sample was washed and dried at $105^{\circ} \mathrm{C}$ for mechanical analysis (Folk 1974). The total organic carbon (TOC) content was determined by oxidation (Loring and Rantala 1992). Total carbonates were estimated as described by Molnia (1974). The total, inorganic, and organic phosphorus contents (TP, IP and OP) were determined (Murphy and Riley 1962; Aspila 1976). Fine powder sediment samples were digested in closed Teflon vessels with a mixture of concentrated $\mathrm{HNO}_{3}, \mathrm{HClO}_{4}$, and $\mathrm{HF}$ acids (3: 2: $1 \mathrm{v} / \mathrm{v}$, respectively; Oregioni and Aston 1984). Heavy metals concentrations were measured in the sediment solution digested using a Flame-Atomic Absorption Spectrophotometer (FAAS, Shimadzo 6800, with Autosampler 6100). Na, K, and Li concentrations were measured using a flame photometer (JENWAY PEP7). Calcium and magnesium levels were volumetrically determined (APHAAWWA-WPCF 1999). Total boron concentration was determined by curcumin colorimetric method (Bingham 1982). Fluoride was extracted following the fusion procedure (Jeffery 1975). Fluoride ion concentration was determined by a colorimetric procedure for zirconium alizarin red S. (Anselm and Robinson 1951; Masoud et al. 2004). Colorimetric determination of both boron and fluoride was performed by UNICO UV-2000 spectrophotometer.

\section{Quality assurance}

The accuracy of the chemical analysis was verified with a sediment reference material (IAEA-405, International Atomic Energy Agency, Austria), which was analyzed with sediment samples during analysis. Results indicated good agreement between the reference material and analytical levels with recovery rates for heavy metals selected from the standard reference material of $95.5-100.2 \%$.

\section{Environmental risk assessment of heavy metals}

Some indices $\left(E F, I_{g e o}, C F, C_{d}, m C_{d}, P L I, R I, T R I, T U s, m P E L Q, m E R M Q, H Q_{\text {sed }}\right.$ and $\left.m H Q_{\text {sed }}\right)$ were applied to verify the geological and anthropogenic sources of heavy metals in the different harbors examined (Table 1). Variation in pollution and ecological risk indices results from the difference in the applicability of these indices to sediment pollutants (Omran 2016).

Table 1 The applied risk assessment indices 


\begin{tabular}{|c|c|c|c|}
\hline Pollution indicators & Procedures of calculation & Definition of parameters & References \\
\hline Enrichment factor $(E F)$ & $E F=\frac{C_{i} \text { sediment }}{\left(\text { Median } C_{i} \text { Sediment }+2 \times M A D C_{b}\right)}$ & $\begin{array}{l}\text { Where, } C_{t} \text { sediment and Median } C_{b} \text { Background were concentration and } \\
\text { median concentration of sediments and background of the determined } \\
\text { heavy element, respectively. } M A D \text { was the median absolute deviation from } \\
\text { median. }\end{array}$ & Khalil et al. 2016 \\
\hline $\begin{array}{l}\text { Geoaccumulation index } \\
\left(I_{g}\right)\end{array}$ & $I_{g e 0}=\log _{2}\left[C_{i} /\left(1.5 \times B_{i}\right)\right.$ & $\begin{array}{l}\text { Where, } \mathrm{Ci} \text { is the measured concentration of metal (i) in the sediments, } B_{\mathrm{i}} \text { is } \\
\text { the geochemical background concentration of the metal (earth crust, and } \\
1.5 \text { is introduced to minimize the effects of possible variations in the } \\
\text { background values. }\end{array}$ & Müller (1969) \\
\hline $\begin{array}{l}\text { Contamination factor } \\
(C F), \text { Degree of } \\
\text { contamination }\left(C_{d}\right) \text {, and } \\
\text { modified degree of } \\
\text { contamination }\left(m C_{d}\right)\end{array}$ & $\begin{array}{l}C F_{i}=\frac{C_{i}}{C_{b}} \\
C_{d}=\sum_{i=1}^{n} C F_{i} \\
m C_{d}=\frac{\sum_{i=1}^{n} C F_{i}}{n}\end{array}$ & $\begin{array}{l}\text { Where, } \mathrm{n} \text { is the number of heavy metals, } C F_{i} \text { is the contamination factor of } \\
\text { the heavy metal in the sediment sample and } C_{b} \text { is the concentration of the } \\
\text { metal in the earth crust. }\end{array}$ & $\begin{array}{l}\text { Ashayeri and Keshavarzi } \\
(2019)\end{array}$ \\
\hline $\begin{array}{l}\text { Pollution load index } \\
(P L I)\end{array}$ & $\begin{array}{l}P L I=\left(C F_{1} \times C F_{2} \times C F_{3} \times \ldots \times C F_{n}\right)^{1 / n} \\
P L I \text { for zone } \\
=\sqrt[m]{\text { station } 1 \times \text { station } 2 \ldots \times \text { station } m}\end{array}$ & $\begin{array}{l}\text { Where } C F \text { is the contamination factor for each of the } \mathrm{n} \text { metal and } \mathrm{m} \\
\text { number of stations in each zone }\end{array}$ & Ganugapenta et al. (2018) \\
\hline $\begin{array}{l}\text { Potential ecological risk } \\
\text { factor }\left(E_{r}\right) \text { and potential } \\
\text { ecological risk index }(R I)\end{array}$ & $\begin{array}{l}E_{r}=T_{i} \mathrm{X} C F_{i} \\
R I=\sum_{i=1}^{n} E_{r}^{i}\end{array}$ & $\begin{array}{l}\text { Where, toxic-response factor }\left(T r_{i}\right) \text { for } \mathrm{Cd}, \mathrm{Cu}, \mathrm{Pb}, \mathrm{Ni}, \mathrm{Cr}, \mathrm{Zn}, \mathrm{Mn} \text { are } 30,5 \text {, } \\
5,5,2,1,1 \text {, respectively, and } C F_{i} \text { is the contamination factor. } \\
\text { Where } R I \text { is the requested potential ecological risk index for the } \\
\text { environment and } E^{\prime} \text {, is the potential ecological risk factor for a given } \\
\text { element i. }\end{array}$ & $\begin{array}{l}\text { Hakanson (1980); Ibrahim et al. } \\
2019\end{array}$ \\
\hline $\begin{array}{l}\text { Toxic risk index }\left(T R I_{i}\right) \\
\text { and integrated }\left(\sum T R I\right)\end{array}$ & $\begin{array}{l}T R I_{i}=\sqrt{\left(C_{i} / T E L\right)^{2}+\left(C_{i} / P E L\right)^{2} / 2} \\
T R I=\sum_{n=1}^{i} T R I_{i}\end{array}$ & $\begin{array}{l}C_{l,}, T E L \text { and } P E L \text { are concentration, threshold and probable level effects of } \\
\text { each heavy metal in sediment sample }\end{array}$ & Elsagh et al. (2021) \\
\hline $\begin{array}{l}\text { Toxic units }(T U s) \text { and } \\
\text { sum of toxic units } \\
\left(\sum T U s\right)\end{array}$ & $\sum T U_{s}=\sum_{i=1}^{n}\left(C_{i} / P E L_{i}\right)$ & $\begin{array}{l}\text { toxic unit }(T U s) \text { is defined as the ratio of each determined trace metal } \\
\text { concentration to its } P E L_{i} \text { value }\end{array}$ & Pederson et al. (1998) \\
\hline $\begin{array}{l}\text { Mean } P E L \text { and } E R M \\
\text { quotients }\end{array}$ & $\begin{array}{l}m-E R M-Q \text { or } m-P E L-Q \\
\qquad=\left(\sum^{n}\left[C_{i} /\left(E R M_{i} \text { or } P E L_{i}\right)\right]\right) / n\end{array}$ & $\begin{array}{l}C_{i} \text { is the concentration, } E R M_{t} \text { is the threshold effect level, and } P E L_{t} \text { is the } \\
\text { probable effect level of each heavy metal }\end{array}$ & $\begin{array}{l}\text { Long et al. (2000); E1 Nemr and } \\
\text { El-Said (2017) }\end{array}$ \\
\hline $\begin{array}{l}\text { Sediment modified } \\
\text { hazard quotient }\left(m H Q_{\text {sed }}\right)\end{array}$ & $m H Q_{\text {sed }}=\left[C_{i}\left(\frac{1}{T E L_{i}}+\frac{1}{P E L_{i}}+\frac{1}{S E L_{i}}\right)\right]^{1 / 2}$ & $\begin{array}{l}\text { Where, } C_{i} \text { is the concentration of the heavy metal, and } T E L_{i}, P E L_{i} \text {, and } S E L_{i} \\
\text { are the threshold effect level, probable effect level, and severe effect level } \\
\text { for i metal, respectively. }\end{array}$ & $\begin{array}{l}\text { Macdonald et al. (2000); El- } \\
\text { Alfy et al. } 2020\end{array}$ \\
\hline $\begin{array}{l}\text { Sediment hazard } \\
\text { quotients }\left(H Q_{s e d}\right)\end{array}$ & $H Q_{\text {sed }}=\frac{C_{i}}{S Q G}$ & $\begin{array}{l}\text { Where, } C_{t} \text { is the observed concentration of a metal in sediment and SQG is } \\
\text { the sediment quality guideline (Urban and Cook, } 1986 \text { ). The } S Q G \text { adopted } \\
\text { for calculating the } H Q Q_{\text {sed }} \text { in this study was the threshold effects level (TEL) }\end{array}$ & El-Alfy et al. 2020 \\
\hline
\end{tabular}

\section{Human health risk assessment}

Exposure to toxic heavy metals may be of great concern to humans who live near polluted aquatic ecosystems. There are two pathways of exposure to heavy metals in sediments, called ingestion (Ing), and dermal (Derm). These exposures can be calculated using equations below equations (Kusin et al. 2018):

$$
\begin{aligned}
& C D I_{\text {Ing }}=\frac{C_{\text {sed }} \times I n g R_{\text {sed }} \times E D \times E F \times C F}{B W \times A T} \\
& C D I_{\text {Derm }}=\frac{C_{\text {sed }} \times S A \times A F \times E F \times A B S \times E D \times C F}{B W \times A T}
\end{aligned}
$$

The exposure factors used in the calculation of chronic daily intake $(C D I)$ are given (Table 2). The potential non-carcinogenic risk of heavy metal concentrations in sediments is characterized by the use of the hazard quotient $(H Q)$. According to US Environmental Protection Agency, the hazard quotient $(H Q)$ is defined as the ratio of the chronic daily intake or dose (CDl; $\mathrm{mg} / \mathrm{kg} /$ day) to reference dose (RfD; $\mathrm{mg} / \mathrm{kg} / \mathrm{day}$; USEPA 2012) as shown (Kusin et al. 2018; ):

$$
H Q=\frac{C D I}{R f D}
$$


Table 2

The exposure factors and their identified values of human health assessment equations based on (USEPA 2011).

\begin{tabular}{|ll|}
\hline Exposure factors & Identify value \\
\hline$C_{\text {sed }}$ & Heavy metal concentration $(\mathrm{mg} / \mathrm{kg})$ \\
\hline$E D$ & Exposure duration of adult (35 years) and child (6 years) \\
\hline$E F$ & Exposure frequency $(312$ days $/$ year) \\
\hline$B W$ & Body weight of adult $(70 \mathrm{~kg})$ and child $(15 \mathrm{~kg})$ \\
\hline$A T$ & Averaging time of adult and child $(365 \times E D)$ \\
\hline$I n g R_{\text {sed }}$ & Ingestion rate of adult $(100 \mathrm{mg} / \mathrm{kg})$ and child $(200 \mathrm{mg} / \mathrm{kg})$ \\
\hline$C F$ & Conversion factor $\left(1 \times 10^{-6} \mathrm{~kg} / \mathrm{mg}\right)$ \\
\hline$S A$ & Skin exposed area of adult $\left(6032 \mathrm{~cm}{ }^{2}\right)$ and child $\left(2373 \mathrm{~cm}^{2}\right)$ \\
\hline$A F$ & Skin adherence factor for sediment of adult $\left(0.07 \mathrm{mg} / \mathrm{cm}^{2}\right)$ and for child $\left(0.2 \mathrm{mg} / \mathrm{cm}^{2}\right)$ \\
\hline$A B S$ & Dermal absorption factor $(0.001)$ \\
\hline$L C R$ & Lifetime cancer risk (mg/kg/day) \\
\hline
\end{tabular}

The total hazard quotient (THQ) of heavy metals ( $($ ) in the sediment harbors for children and adults is calculated (El-Sadaawy et al. 2013; Liu et al. 2020):

$$
T H Q=\sum H Q_{i}=H Q_{F e}+H Q_{M n} \cdots \ldots . H Q_{C d}
$$

$H I$ is a combination of THQ's traditional exposure pathways with the same detrimental effect. $H Q$ values less than 0.2 are allowed, while value greater than 0.2 not and $T H Q$ values $<1$ show no exposure risk. Similarly, an $H /$ of greater than unity from various pathways is considered unacceptable which means that the exposed population may experience adverse health effect and risk management measures should be implemented while $\mathrm{HI}$ of less than unity is considered negligible (Kusin et al. 2018):

$$
H I=\sum T H Q_{i n g}+T H Q_{d e r m}
$$

According to $H /$ values, no significant risk of non-carcinogenic will be expected if the value is less than one $(H I<1)$. However, if $H I$ value exceeds one $(H I>1)$, there is a possibility of non-carcinogenic risk effects that tend to increase as the H/value increases.

On the other hand, the health risk for carcinogenic heavy metals expressed through incremental excess lifetime cancer risk (IELCR) was determined by estimating the total value of cancer risks for each of the exposure pathways (Table 2). Where, the cancer slope factor (CSF) values for Cd, Cr and Pb are 6.3, $0.5,0.0085$ and $1.5 \mathrm{mg} / \mathrm{kg} /$ day (USEPA 2012). Where, LADD is lifetime average daily dose and incremental excess lifetime cancer risk (IELCR) can be calculated from the following equation (Johnbull et al. 2019):

$$
I E L C R=L A D D \times C S F
$$

The sum the carcinogenic effect from exposure to carcinogenic pollutants gives the cumulative target risk (CTR) (Johnbull et al. 2019), while, TLCR represents the sum of CTR in this equation (Li et al. 2021):

$$
\begin{gathered}
C T R=\sum_{i} L E L C R_{i} \\
T L C R=\sum C T R_{\text {Ing }}+C T R_{\text {Derm }}
\end{gathered}
$$

The acceptable threshold value for total lifetime cancer risk (TLCR) is between 1.0E-06 and 1.0E-04 that does not cause adverse human health risks (USEPA 2012; Johnbull et al. 2019; Li et al. 2021). Whereas, there may be significant public health risks above $1.0 \mathrm{E}-04$ which makes the decision makers take notice.

\section{Principal component analysis (PCA)}

The statistical analysis of the physico-chemical and heavy metals characterization of sediments was performed by the SPSS-19 program. Principal component analysis (PCA) can assess the relationship between examined heavy metals and can also explore the hypothetical sources of heavy metals from both natural and anthropogenic origins (Bhardwaj et al. 2017).

\section{Results And Discussion}

Sediment characterization

The grain size data reveal that the sediments in Sidi Krir Harbor (A) composed of different types of sand fractions (coarse, medium, fine). The mean size ranges between $0.45 \Phi$ and $2.59 \Phi$ with average value $1.54 \Phi$ (Table 3). The mean size in Dekhila Harbor (B) fluctuates from $3.33 \Phi$ (very fine sand) to $6.19 \Phi$ 
(fine silt) with an average value $4.68 \Phi$. The occurrence of fine sediments here may be due to the dominance of terrigenous fine grain size sediments. The inclusive graphic mean size (MZФ) of the Western Harbor $(C)$ ranges between $2.08 \Phi$ (fine sand) and 6.22 $\Phi$ (fine silt) with the average value $4.34 \Phi$. It was found that, the majority of sediments consist mainly of silt fractions covering the bottom. In Damietta Harbor (D), the mean size ranges from 5.75 to $6.17 \Phi$. In this harbor the majority of sediments covering the bottom are silt (fine, and medium). The mean size in Port Said Harbor (E) varies between 3.00 (very fine sand) and 7.04 (very fine silt). However, the differences in grain size distribution can be attributed to the bottom configuration and dominant current regime.

Table 3

Sediment charactrization of sediments of studied harbors

\begin{tabular}{|c|c|c|c|c|c|c|c|c|c|c|c|c|c|c|c|c|}
\hline \multirow{2}{*}{$\begin{array}{l}\text { Sediment } \\
\text { characterization }\end{array}$} & \multicolumn{4}{|c|}{ SidiKrir Harbor } & \multicolumn{4}{|c|}{ Dekhila Harbor (B) } & \multicolumn{4}{|c|}{ Westem Harbor ( C) } & \multicolumn{4}{|c|}{ Damietta Harbor (D) } \\
\hline & Min. & Max. & Av. & SD & Min. & Max. & Av. & SD & Min. & Max. & Av. & SD & Min. & Max. & Av. & $S$ \\
\hline Sand (\%) & 99.8 & 100.0 & 99.9 & 0.1 & 5.9 & 57.9 & 32.5 & 24.8 & 24.1 & 78.6 & 39.3 & 22.2 & 4.0 & 39.4 & 17.6 & 1 \\
\hline Silt (\%) & 0.0 & 0.4 & 0.1 & 0.2 & 31.3 & 72.6 & 52.5 & 19.1 & 15.6 & 67.1 & 45.3 & 17.6 & 29.2 & 87.7 & 53.0 & 21 \\
\hline Clay (\%) & 0.0 & 0.0 & 0.0 & 0.0 & 8.6 & 25.4 & 15.0 & 6.7 & 5.8 & 18.6 & 15.4 & 5.4 & 8.4 & 46.8 & 29.5 & 11 \\
\hline Mean $(\Phi)$ & 0.45 & 2.59 & 1.54 & 0.8 & 3.33 & 6.16 & 4.68 & 1.2 & 2.08 & 6.22 & 4.34 & 1.5 & 5.75 & 6.17 & 6.0 & 0. \\
\hline Sorting $(\varnothing)$ & 0.8 & 1.2 & 1.0 & 0.2 & 0.8 & 3.0 & 2.1 & 0.9 & 2.05 & 3.31 & 2. 58 & 0.4 & 1.15 & 2.57 & 2.0 & 0. \\
\hline Skweness & -0.3 & 0.2 & 0.0 & 0.2 & -0.4 & 0.4 & 0.1 & 0.3 & -0.2 & 0.3 & 0.1 & 0.2 & -0.5 & 0.3 & -0.1 & 0. \\
\hline Kurtosis & 0.8 & 1.6 & 1.0 & 0.3 & 1.0 & 2.2 & 1.3 & 0.5 & 0.9 & 2.0 & 1.3 & 0.4 & 0.7 & 2.2 & 1.3 & 0. \\
\hline$A(\%)$ & 14.7 & 22.2 & 17.94 & 2.7 & 49.4 & 67.9 & 57.9 & 8.3 & 56.8 & 65.9 & 61.21 & 3.9 & 40.3 & 54.6 & 48.33 & 6. \\
\hline TOC (\%) & 0.1 & 0.2 & 0.1 & 0.1 & 2.4 & 4.0 & 3.1 & 0.7 & 1.7 & 5.6 & 4.5 & 1.5 & 1.0 & 1.7 & 1.4 & 0. \\
\hline $\mathrm{TCO}_{3}(\%)$ & 84.0 & 99.6 & 92.5 & 7.3 & 79.4 & 88.6 & 82.9 & 4.1 & 20.1 & 90.5 & 66.1 & 24.0 & 11.1 & 20.2 & 16.0 & 3. \\
\hline $\mathrm{TSiO}_{3}(\%)$ & 0.0 & 16.0 & 8.0 & 7.0 & 11.4 & 20.6 & 17.2 & 4.1 & 9.5 & 79.9 & 33.9 & 24.0 & 79.8 & 89.0 & 84.0 & 3. \\
\hline $\mathrm{TP}(\mu \mathrm{g} / \mathrm{g})$ & 30.0 & 121.0 & 62.0 & 40.0 & 250.0 & 933.0 & 640.0 & 312.0 & 649.0 & 913.0 & 771.0 & 87.0 & 671.0 & 914.0 & 769.0 & 9 \\
\hline IP $(\mu \mathrm{g} / \mathrm{g})$ & 16.0 & 92.0 & 38.0 & 32.0 & 205.0 & 743.0 & 484.0 & 247.0 & 482.0 & 882.0 & 634.0 & 149.0 & 648.0 & 710.0 & 680.0 & 2 \\
\hline $\mathrm{OP}(\mu \mathrm{g} / \mathrm{g})$ & 11.0 & 42.0 & 24.0 & 12.0 & 45.0 & 215.0 & 155.0 & 71.0 & 31.0 & 244.0 & 138.0 & 87.0 & 16.0 & 204.0 & 89.0 & 71 \\
\hline $\mathrm{Ca}(\mathrm{mg} / \mathrm{g})$ & 169.1 & 373.7 & 298.6 & 83.9 & 367.4 & 709.7 & 580.1 & 129.6 & 292.0 & 595.3 & 501.9 & 111.8 & 109.2 & 346.7 & 213.0 & $9 i$ \\
\hline $\mathrm{Mg}(\mathrm{mg} / \mathrm{g})$ & 240.5 & 482.6 & 385.4 & 98.7 & 402.0 & 736.8 & 625.1 & 128.9 & 370.6 & 745.2 & 606.8 & 155.8 & 93.5 & 435.8 & 234.4 & 1 . \\
\hline $\mathrm{Na}(\mathrm{mg} / \mathrm{g})$ & 7.7 & 21.3 & 14.3 & 5.1 & 25.3 & 30.2 & 28.2 & 1.8 & 15.3 & 19.1 & 17.2 & 1.5 & 18.6 & 37.7 & 26.1 & 7. \\
\hline $\mathrm{K}(\mathrm{mg} / \mathrm{g})$ & 0.0 & 0.2 & 0.1 & 0.1 & 0.8 & 1.2 & 1.1 & 0.2 & 0.8 & 1.8 & 1.6 & 0.4 & 2.3 & 3.3 & 3.0 & 0. \\
\hline $\mathrm{Li}(\mu \mathrm{g} / \mathrm{g})$ & 0.8 & 15.3 & 3.7 & 6.5 & 115.9 & 165.9 & 137.7 & 20.3 & 18.6 & 173.6 & 94.2 & 59.1 & 33.8 & 49.9 & 40.7 & 6. \\
\hline $\mathrm{B}(\mathrm{mg} / \mathrm{g})$ & 2.3 & 5.7 & 3.4 & 1.5 & 4.7 & 14.1 & 8.0 & 4.4 & 3.5 & 6.9 & 5.0 & 1.4 & 3.0 & 4.1 & 3.5 & 0. \\
\hline $\mathrm{SO}_{4}(\mathrm{mg} / \mathrm{g})$ & 1.9 & 7.4 & 4.1 & 2.0 & 17.7 & 29.6 & 23.2 & 4.3 & 19.1 & 79.6 & 33.3 & 23.3 & 4.4 & 17.5 & 10.2 & 5. \\
\hline $\mathrm{Cl}(\mathrm{mg} / \mathrm{g})$ & 0.4 & 0.5 & 0.5 & 0.1 & 2.0 & 2.5 & 2.3 & 0.2 & 2.6 & 5.2 & 3.8 & 1.2 & 1.7 & 4.5 & 2.8 & 1. \\
\hline $\mathrm{F}(\mathrm{mg} / \mathrm{g})$ & 0.31 & 0.56 & 0.42 & 0.10 & 0.18 & 0.57 & 0.51 & 0.16 & 0.37 & 0.62 & 0.51 & 0.09 & 0.13 & 0.55 & 0.27 & 0. \\
\hline
\end{tabular}

In Sidi Krir Harbor (A), the classification of sediments varies from moderately to poorly sorted $\Phi$ (Table 3). Whereas, in Dekhila Harbor (B), the sediments characteristics range between poorly sorted $(0.80 \Phi)$ and very poorly sorted $(3 \Phi)$. Poor sediments or ting mainly caused by the crushing the calcareous shells into fragments. At Western Harbor (C), the entire sediments are very poorly sorted. It varies between $2.05 \Phi$ and $3.31 \Phi$ with average value 2.58 . The sediments in Damietta (D) and Port Said (E) harbors vary from poorly sorted (1.15 and $0.71 \Phi$, respectively) to very poorly sorted (2.57 and $2.52 \Phi$, respectively). It was suggested that poorly sorted sediments indicate a variable or disturbance during sedimentation (Wigley 1961). The main factors controlling sorting are the range of the particle size of materials the supplied to environments, the types of deposition and the current characteristics (Yang and Sh 2019).

The percentage of water content (A \%) well reflects the sediment texture of the examined sediment samples, and the variation in all different samples is relatively slight, while there is significant variation between the five studied harbors studied (Table 3). The harbor of Sidi Krir scores the lowest average $A$ (17.94\%), while the highest average is determined for the harbors of Dekhila and Western (57.90 and 61.21\%, respectively). Harbors of Damietta and Port Said show relatively similar percentages of 48.33 and 46.08 , respectively. For Dekhila Harbor, the displays results show good correlation between $\mathrm{A} \%$ and each of TP \% ( $r=0.9647, p \leq 0.008)$, IP ( $r=0.9830, p \leq 0.003)$, Fe ( $r=0.9580, p \leq 0.010), M n(r=0.8957, p \leq 0.040)$, and Zn ( $r=0.9560, p \leq 0.011)$. A\% Damietta Harbor gives a weak correlation with TOC\% ( $r=0.8800, p \leq 0.049)$, while, Port Said Harbor explores good correlations between A \% and each of TOC\% ( $r=0.9326$, $\mathrm{p} \leq 0.021), \mathrm{TCO}_{3}(\mathrm{r}=0.9865, \mathrm{p} \leq 0.002)$, and $\mathrm{Cl}(\mathrm{r}=0.9412, \mathrm{p} \leq 0.017)$. In contrast, $\mathrm{A} \%$ does not specify any relationship to the sediment components of Sidi Krir and Western harbors. These correlations could be related to the uptake of the previously mentioned parameters at the inner surfaces as well as their condensation in the capillaries of the small pores. 
Sorting $(\varnothing)$ of the sediment indicates the fluctuation in the degree of kinetic energy and the effect of sedimentation system on the grain size characteristics (ElSaid et al. 2014). It ranges from poorly sorted to very poorly indicating troubled conditions. Most of the sediments are observed from poorly sorted in Sidi Krir to very poorly locate in Western Harbor, Damietta and Port Said Harbor (Table 3).

Skewness values give information about the symmetry or asymmetry of the frequency distribution of the sediment, and the sign of skewness correlates with environmental energy (Bhattacharya et al. 2016).

Kurtosis plays a vital role in sediment characterization in different environments as explained by Duane (1964) It is also working as on internal sorting or distribution. Friedman (1962) suggested that very high or low values of kurtosis mean that a portion the sediment has achieved sorting elsewhere in a highenergy environment. Almost all studied samples are leptokurtic. It has been suggested that carbonate sands tend to be exclusively leptokurtic or peaked (Pikey et al. 1967). This is related to the dominance of the carbonate sands (El-Said et al. 2014).

Among the examined harbors sediments, the organic carbon content (TOC\%) show high values in both the Dekhila and Western harbors (Table 3). TOC\% at Dekhila Harbor ranges between 2.4 and $4.0 \%$, while, the higher value is limited to station 3 , which includes agricultural drainage, sewage, and industrial wastewater from Lake Mariout through El Umoum drain, heavy ship traffic, export, and import activities. And the high values of TOC\% (1.74 - 5.63\%) are recorded in most of the Western Harbor stations, which are severely affected by agricultural runoff from the El-Mahmoudiya and Noubaria canals and are also affected by household waste. Generally, the low organic carbon content in most harbor sediments is due to reduced bioactivity and good aeration of bottom sediments, as most of the sediment organic matter is oxidized and washed out. The distribution of total organic carbon in the studied harbor sediments is strongly influenced by the amount of $\mathrm{CaCO}_{3}$.

The total silicate content ranges between the maximum (84.0\%) value in Damietta and the minimum in Sidi Krir Harbor (8.0\%; Table 3). Total silicate contents show the opposite trend to the carbonate contents along the area of investigation.

The data presented reflect those sediments of Sidi Krir Harbor show the lowest average TP, IP and OP contents $(62.0,38.0$ and $24.0 \mu \mathrm{g} / \mathrm{g}) \mathrm{among}$ the other studied harbors (Table 3). OP content ranges from 11 to $42 \mu \mathrm{g} / \mathrm{g}$ with an average value $(24 \mu \mathrm{g} / \mathrm{g})$, representing $39 \%$ of the TP content. The correlation matrix yields high modulus values for TP\&TOC\% and IP\&TOC\% ( $r=0.9881, p \leq 0.002$ and $r=0.9901, p \leq 0.001$, respectively), indicating the autolysis of dead cells of benthic organisms and their activities using phosphorus content (Pakzad et al. 2014).

The TP in the sediment harbors of Western Harbor and Damietta have higher average values (771.0 and $769.0 \mu \mathrm{g} / \mathrm{g}$, respectively) than the other examined harbors. TP, IP and OP content of Dekhila Harbor varies from 250 to $933,205.0$ to 743.0 and 45 to $215 \mu \mathrm{g} / \mathrm{g}$, respectively, where, IP and OP that count by 76 and $24 \%$, respectively of TP. The positive correlations between TP\&Silt\% $(r=0.9875, p \leq 0.002)$ and IP\&Silt $(r=0.995, p \leq 0.000)$ indicate that sediments with smaller grain size (clay and silt) have a greater ability to adsorb P (Jin et al. 2006; Kapanen 2008). Additionally, the presented data reflects the possible adsorption of phosphate with Fe, Mn, and Zn compounds (TP \& Fe; $r=0.9526, p \leq 0.012$, TP \& Mn; $r=0.9157, p \leq 0.029$ and TP \& Zn; $r=0.9332, p \leq 0.021$, respectively). Also, these relations are agreement with the correlations of Fe \& Mean\% ( $r=0.9355, p \leq 0.019), M n \& M e a n \%(r=0.8860, p \leq 0.045), Z n \& M e a n \%(r=$ $0.9673, p \leq 0.007, F e \& A \%(r=0.9580, p \leq 0.010), M n \& A \%(r=0.8957, p \leq 0.040)$, and Zn\&A\% $(r=0.9560, p \leq 0.011)$.

In Western Harbor sediments, the values of TP show high values ranging from 649.0 to $913 \mu \mathrm{g} / \mathrm{g}$. IP contents are between $482 \mathrm{and} 882 \mu \mathrm{g} / \mathrm{g}$ and represented $82 \%$ of the TP, while OP varies between 31 and $244 \mu \mathrm{g} / \mathrm{g}$. Data reveal a significant positive association between TP\& Zn ( $r=0.8994, p \leq 0.015)$, IP\&Ni $(r=$ $0.9401, p \leq 0.005)$ and $\mathrm{OP} \& \mathrm{~Pb}(\mathrm{r}=0.8521, \mathrm{p} \leq 0.031)$ which reflects the potential adsorption of phosphate forms with their compounds. Also, the relationship of TP and $F(r=0.893, p \leq 0.017)$ indicates the formation of fluorapatite $\left(\mathrm{Ca}_{5}\left(\mathrm{PO}_{4}\right)_{3} \mathrm{~F}\right)(\mathrm{El}-\mathrm{Said}$ et al. 2015).

The average concentrations of TP, IP and OP in Damietta Harbor are 769.0,680.0, and $89.0 \mu \mathrm{g} / \mathrm{g}$, respectively. The relationships TP\&Sit\% ( $r=0.8863, \mathrm{p} \leq 0.045)$ and IP\&Sit\% $(r=0.9534, p \leq 0.012)$ show a significant positive association. Mn in the present work reflects high correlations between TP and OP $(r=0.9553$, $\mathrm{p} \leq 0.011$ and $r=0.9856, p \leq 0.002$, respectively). While, IP shows negative significant relationships with $\mathrm{B}$ and $\mathrm{SO}_{4}(\mathrm{r}=-0.9816, \mathrm{p} \leq 0.003$ and $\mathrm{r}=-0.8837$, $\mathrm{p} \leq 0.047$, respectively). Average concentrations of TP, IP and OP for Port Said Harbor are 620, 550 and $65 \mu \mathrm{g} / \mathrm{g}$ respectively and IP content represents about $90 \%$ of the TP. It is observed that TP and IP show a positive correlation with $F(r=0.9249, p \leq 0.024$ and $r=0.9283, p \leq 0.023$, respectively). In general, TP contents in surface sediments of all studied harbors are much significantly higher than those of the Sidi Krir Harbor. This could be because this harbor is relatively remote from the mainland with fewer human impacts such as agricultural activities, so fewer land-based sources of phosphorus would be expected.

Ca $(580.1 \pm 129.6 \mathrm{mg} / \mathrm{g}), \mathrm{Mg}(625.1 \pm 128.9 \mathrm{mg} / \mathrm{g}), \mathrm{Na}(28.2 \pm 1.8 \mathrm{mg} / \mathrm{g}), \mathrm{B}(8.0 \pm 4.4 \mathrm{mg} / \mathrm{g}), \mathrm{F}(0.5 \pm 0.2 \mathrm{mg} / \mathrm{g})$ and Li $(137.7 \pm 20.3 \mu \mathrm{g} / \mathrm{g})$ show the highest average contents at Dekhila Harbor (B) (Table 3). The Ca values determined in this study are relatively similar to those recorded along the Egyptian coast of Mediterranean Sea, but the Mg values detected are higher than those obtained at the Egyptian Mediterranean Sea coast (El-Said et al. 2010). The relationship between Ca and Mg in Dekhila Harbor and Sidi Krir Harbor (A) ( $r=0.9757, p \leq 0.005$ and $r=0.9806, p \leq 0.003$, respectively) may attributed to the formation of aragonite and high Mg calcite (El-Said et al. 2021). The lowest Ca (213.0.1 $\pm 98.8 \mathrm{mg} / \mathrm{g}$ ), and $\mathrm{Mg}(234.4 \pm 142.4 \mathrm{mg} / \mathrm{g})$, average contents are recorded at Damietta Harbor (D). The values recorded for $\mathrm{Na}(7.7-37.7 \mathrm{mg} / \mathrm{g})$ and $\mathrm{K}(0.0-4.9 \mathrm{mg} / \mathrm{g})$ in the current study are lower those recorded for the contaminated Egyptian Lake Mariout (18.33-39.25 mg/g and 0.91-5.99 mg/g, respectively) (El-Said et al. 2020). Minimum Cl (0.5 $\pm 0.1 \mathrm{mg} / \mathrm{g}), \mathrm{K}(0.1 \pm 0.1 \mathrm{mg} / \mathrm{g}), \mathrm{B}(3.4 \pm 1.5$ $\mathrm{mg} / \mathrm{g}), \mathrm{SO}_{4}(4.1 \pm 2.0 \mathrm{mg} / \mathrm{g})$ and $\mathrm{Li}(3.7 \pm 6.5 \mu \mathrm{g} / \mathrm{g})$ contents reflect the minimum amounts of pollutants at Sidi Krir Harbor (A). Relationship between Cl-TOC\% $(r=0.9999, p \leq 0.000) \mathrm{Cl}-\mathrm{IP}(r=0.9901, \mathrm{p} \leq 0.001)$ and Cl-TP $(r=0.9881, \mathrm{p} \leq 0.002)$ at Sidi Krir Harbor and chloride relationships of Cl-TOC\% $(r=0.9329, \mathrm{p} \leq 0.021)$, $\mathrm{TCO}_{3} \%(r=0.8973, \mathrm{p} \leq 0.039)$ and $\mathrm{Cl}-\mathrm{K}(\mathrm{r}=0.9274, \mathrm{p} \leq 0.023)$ are likely related to the water-soluble chloride compounds released and leached during the process of mineralization and weathering in Port Said (Harlove and Aranovich 2018). The highest average fluoride concentration $(0.51 \pm 0.16 \mathrm{mg} / \mathrm{g})$ is recorded at Dekhila Harbor (B), while the lowest $(0.22 \pm 0.04 \mathrm{mg} / \mathrm{g})$ is determined at Port Said Harbor (E). The highest recorded average fluoride content is within the amount of fluoride reported in ocean sediments $(0.45-1.1 \mathrm{mg} / \mathrm{g}$ ) (El-Said et al. 2010; 2016). The average amount of fluoride detected in Damietta Harbor (D) is 
relatively similar to that previously determined in it $(0.25 \pm 0.31)$ (El-Said et al. 2016), whereas, the average value of fluoride recorded in Port Said is lower than that reported previously in this region $(0.49 \pm 0.10)$ (El-Said et al. 2016).

\section{Heavy metals distribution}

The average concentration of heavy metals along the harbors examined indicates that their regions are predominantly Fe and Mn, with the exception of the Sidi Kriri Harbor which is predominantly Fe and Cu (Table 4). Among the heavy metals identified in the harbors, the harbor of Sidi Kriri shows the lowest heavy metal values, with the exception of $\mathrm{Cu}$, which ranks second after the Western Harbor. Along the harbors, cadmium shows the lowest values ranging between 1.06 and $29.99 \mu \mathrm{g} / \mathrm{g}$ in harbors of Damietta and Western, respectively. Generally, the sediment quality guidelines (SQGs) indicate that most of the heavy metals identified ( $\mathrm{Cu}, \mathrm{Ni}, \mathrm{Cr}, \mathrm{Pb}$ and $\mathrm{Cd})$ in the studied harbors rang between TEL and PEL values, with the exception of average Ni in harbors of Dekhila and Port Said, which is more than ERM values and Cd contents which are relatively similar to the ERM. 
Table 4

Heavy metals concentration $(\mu \mathrm{g} / \mathrm{g})$ of sediments of studied harbors

\begin{tabular}{|c|c|c|c|c|c|c|c|c|c|}
\hline Harbor & Station number & $\mathrm{Fe}$ & Mn & $\mathrm{Zn}$ & $\mathrm{Cu}$ & $\mathrm{Ni}$ & $\mathrm{Cr}$ & $\mathrm{Pb}$ & Cd \\
\hline \multirow[t]{5}{*}{ Sidi Krir } & 1 & 212.9 & 27.6 & 57.17 & 43.29 & 3.29 & 3.96 & 11.44 & 2.97 \\
\hline & 2 & 185.6 & 7.7 & 6.11 & 20.02 & 4.25 & 3.79 & 9.08 & 1.45 \\
\hline & 3 & 115.1 & 9.8 & 15.42 & 51.73 & 3.10 & 3.52 & 9.19 & 1.79 \\
\hline & 4 & 257.2 & 33.1 & 21.31 & 79.22 & 4.25 & 4.22 & 3.35 & 1.83 \\
\hline & 5 & 153.4 & 3.1 & 3.54 & 61.03 & 3.17 & 3.52 & 4.53 & 1.81 \\
\hline Minimum & & 115.1 & 3.10 & 3.54 & 20.02 & 3.10 & 3.52 & 3.35 & 1.45 \\
\hline Maximum & & 257.2 & 33.14 & 57.17 & 79.22 & 4.25 & 4.22 & 11.44 & 2.97 \\
\hline Average & & 184.9 & 16.27 & 20.71 & 51.06 & 3.61 & 3.80 & 7.52 & 1.97 \\
\hline S.D & & 54.5 & 13.26 & 21.60 & 21.89 & 0.59 & 0.30 & 3.43 & 0.58 \\
\hline \multirow[t]{5}{*}{ Dekhila } & 6 & 5507.7 & 147.5 & 61.84 & 0.00 & 3.33 & 26.92 & 7.83 & 1.98 \\
\hline & 7 & 6867.2 & 188.4 & 57.59 & 8.77 & 206.14 & 4.29 & 12.31 & 4.07 \\
\hline & 8 & 10569.7 & 275.5 & 176.86 & 3.59 & 24.40 & 10.49 & 19.99 & 3.74 \\
\hline & 9 & 8237.7 & 236.0 & 82.37 & 43.80 & 21.35 & 8.93 & 4.08 & 5.00 \\
\hline & 10 & 10493.5 & 254.2 & 183.46 & 26.18 & 19.06 & 46.43 & 25.70 & 3.91 \\
\hline Minimum & & 5507.7 & 147.48 & 57.59 & 0.00 & 3.33 & 4.29 & 4.08 & 1.98 \\
\hline Maximum & & 10569.7 & 275.50 & 183.46 & 43.80 & 206.14 & 46.43 & 25.70 & 5.00 \\
\hline Average & & 8335.2 & 220.32 & 112.43 & 16.47 & 54.86 & 19.41 & 13.98 & 3.74 \\
\hline S.D & & 2225.5 & 51.86 & 62.58 & 18.28 & 84.96 & 17.35 & 8.84 & 1.10 \\
\hline \multirow[t]{6}{*}{ Western } & 11 & 6633.4 & 209.5 & 208.47 & 886.98 & 54.29 & 14.96 & 17.48 & 4.05 \\
\hline & 12 & 9555.9 & 285.8 & 267.43 & 72.49 & 10.81 & 45.88 & 104.67 & 3.17 \\
\hline & 13 & 8606.4 & 313.4 & 290.48 & 114.64 & 70.83 & 99.32 & 14.65 & 5.38 \\
\hline & 14 & 6929.1 & 282.6 & 278.83 & 159.20 & 8.04 & 4.33 & 124.80 & 3.37 \\
\hline & 15 & 11312.1 & 273.3 & 133.57 & 101.05 & 6.51 & 73.72 & 12.82 & 5.50 \\
\hline & 16 & 11103.4 & 349.4 & 215.05 & 66.35 & 3.87 & 544.78 & 129.92 & 29.99 \\
\hline Minimum & & 6929.1 & 273.26 & 133.57 & 66.35 & 3.87 & 4.33 & 12.82 & 3.17 \\
\hline Maximum & & 11312.1 & 349.43 & 290.48 & 159.20 & 70.83 & 544.78 & 129.92 & 29.99 \\
\hline Average & & 9501.4 & 300.90 & 237.07 & 102.75 & 20.01 & 153.60 & 77.37 & 9.48 \\
\hline S.D & & 1821.1 & 30.98 & 64.64 & 37.32 & 28.52 & 221.49 & 58.86 & 11.51 \\
\hline \multirow[t]{5}{*}{ Damietta } & 17 & 18212.6 & 840.9 & 104.44 & 28.96 & 127.34 & 97.94 & 9.30 & 1.23 \\
\hline & 18 & 17305.8 & 917.7 & 134.40 & 50.64 & 151.53 & 79.23 & 111.55 & 8.96 \\
\hline & 19 & 17513.6 & 553.9 & 87.48 & 32.34 & 134.99 & 84.27 & 8.50 & 1.06 \\
\hline & 20 & 17829.3 & 1280.0 & 93.73 & 29.51 & 158.29 & 84.34 & 8.70 & 1.87 \\
\hline & 21 & 17995.5 & 796.9 & 96.72 & 37.44 & 175.44 & 83.73 & 9.01 & 2.04 \\
\hline Minimum & & 17305.8 & 553.85 & 87.48 & 28.96 & 127.34 & 79.23 & 8.50 & 1.06 \\
\hline Maximum & & 18212.6 & 1280.03 & 134.40 & 50.64 & 175.44 & 97.94 & 111.55 & 8.96 \\
\hline Average & & 17771.4 & 877.88 & 103.36 & 35.78 & 149.52 & 85.90 & 29.41 & 3.03 \\
\hline S.D & & 364.5 & 262.79 & 18.39 & 8.96 & 19.08 & 7.06 & 45.92 & 3.34 \\
\hline \multirow[t]{4}{*}{ Port Said } & 22 & 17015.4 & 1205.3 & 127.82 & 47.02 & 138.49 & 149.76 & 30.31 & 3.35 \\
\hline & 23 & 16795.2 & 1001.9 & 138.35 & 54.16 & 114.42 & 107.54 & 40.16 & 2.16 \\
\hline & 24 & 16967.8 & 1338.1 & 108.12 & 34.74 & 135.15 & 73.55 & 4.19 & 2.15 \\
\hline & 25 & 15551.9 & 615.3 & 63.85 & 6.57 & 76.75 & 126.25 & 3.37 & 1.50 \\
\hline
\end{tabular}




\begin{tabular}{|c|c|c|c|c|c|c|c|c|c|}
\hline Harbor & Station number & $\mathrm{Fe}$ & Mn & Zn & $\mathrm{Cu}$ & $\mathrm{Ni}$ & $\mathrm{Cr}$ & $\mathrm{Pb}$ & $\mathrm{Cd}$ \\
\hline & 26 & 18048.9 & 1176.8 & 105.38 & 27.20 & 150.77 & 174.57 & 11.72 & 1.94 \\
\hline Minimum & & 15551.9 & 615.35 & 63.85 & 6.57 & 76.75 & 73.55 & 3.37 & 1.50 \\
\hline Maximum & & 18048.9 & 1338.10 & 138.35 & 54.16 & 150.77 & 174.57 & 40.16 & 3.35 \\
\hline Average & & 16875.8 & 1067.49 & 108.70 & 33.94 & 123.11 & 126.33 & 17.95 & 2.22 \\
\hline S.D & & 889.3 & 279.69 & 28.58 & 18.54 & 29.03 & 38.78 & 16.48 & 0.69 \\
\hline \multicolumn{10}{|c|}{ Sediment quality guidelines (SQGS) } \\
\hline TEL & & & & 124 & 18.7 & 15.9 & 52.3 & 30.2 & 0.68 \\
\hline$P E L$ & & & & 271 & 108 & 42.8 & 160 & 112 & 4.2 \\
\hline$E R L$ & & & & 150 & 34 & 30 & 81 & 46.7 & 1.2 \\
\hline$E R M$ & & & & 410 & 270 & 50 & 370 & 218 & 9.6 \\
\hline
\end{tabular}

The correlation matrix for the studied parameters for each harbor shows that the heavy metals examined contribute to the sediment contamination and the geochemical properties of the sediments. In Sidi Krir Harbor this contribution is shown in the correlations of $\mathrm{Cr}-\mathrm{Fe}(\mathrm{r}=0.9685, \mathrm{p} \leq 0.007), \mathrm{Cr}-\mathrm{Mg}$ ( $\mathrm{r}=0.9033$, $\mathrm{p} \leq$ 0.036), Cd-Zn ( $r=0.9505, \mathrm{p} \leq 0.013), \mathrm{Cd}-\mathrm{Li}(\mathrm{r}=0.9451, \mathrm{p} \leq 0.015)$, and Cu-Na ( $r=-0.9433, \mathrm{p} \leq 0.016)$. In Dekhila Harbor Fe-K( $r=0.9146, p \leq 0.030), \mathrm{Mn}-\mathrm{K}$ $(r=0.9301, p \leq 0.022), \mathrm{Ni}-\mathrm{B}(r=0.9456, p \leq 0.015), \mathrm{Ni}-\mathrm{Cl}(r=-0.9675, p \leq 0.007), \mathrm{Cd}-\mathrm{Ca}(r=0.9798, p \geq 0.003)$, and Cd-Mg ( $r=0.9748, p \geq 0.005)$ are obtained. In Western Harbor, heavy metals accumulation in sediments due to pollution sources is demonstrate by the following correlations of $\mathrm{Zn}-\mathrm{Li}(\mathrm{r}=0.8430$, $\mathrm{p} \geq 0.035$ ), $\mathrm{Zn}-\mathrm{F}(\mathrm{r}=0.8519, \mathrm{p} \geq 0.031), \mathrm{Cd}-\mathrm{Cr}(\mathrm{r}=0.9934, \mathrm{p} \geq 0.000)$, and Pb-B ( $r=-0.9553, p \geq 0.003)$. In Damietta Harbor, the relationships of $\mathrm{Zn}-\mathrm{Pb}(\mathrm{r}=0.9456 \mathrm{p} \geq 0.015), \mathrm{Zn}-$ $\mathrm{Cd}(r=0.9406, p \geq 0.017), \mathrm{Cd}-\mathrm{Pb}(\mathrm{r}=0.9924, \mathrm{p} \geq 0.001), \mathrm{Zn}-\mathrm{Ca}(\mathrm{r}=0.9024, \mathrm{p} \geq 0.036), \mathrm{Zn}-\mathrm{Mg}(\mathrm{r}=0.9241, p \geq 0.024), \mathrm{Zn}-\mathrm{K}(\mathrm{r}=0.9487, p \geq 0.014), \mathrm{Pb}-\mathrm{K}(\mathrm{r}=0.9218$, $p \geq 0.026)$, and Cd-K ( $r=0.9497, p \geq 0.013)$ are obtained. In Port Said, there are many correlations between Ni-Fe ( $r=0.9468, p \geq 0.015), N i-M n(r=0.9217$, $p \geq 0.026), Z n-C u(r=0.9902, p \geq 0.001), Z n-L i(r=0.9349, p \geq 0.020), C r-N a(r=0.9211, p \geq 0.026), C d-L i(r=0.8879 p \geq 0.044), C d-F(r=0.9355, p \geq 0.019), C d-K$ $(r=0.9673 p \geq 0.007)$, and $\mathrm{Cd}-\mathrm{Cl}(r=0.8916 \mathrm{p} \geq 0.042)$. The large amount of heavy metals may be related to the wastewater evacuation of phosphate fertilizers and untreated industrial pollutants, along with shipping activities. These correlations coincide with the high significant multiple regression equations (Table 5). 
Multiple regression analyses of heavy metals and different geochemical properties in the examined harbors

\begin{tabular}{|c|c|c|}
\hline Harbor & Multiple regression equation & $\mathbf{R}$ \\
\hline \multirow[t]{8}{*}{ Sidi Krir } & $\mathrm{Fe}=-191.7+0.40 \mathrm{Cr}+0.56 \mathrm{Mg}-0.15 \mathrm{Na}$ & 0.9998523 \\
\hline & $\mathrm{Mn}=-233.6+1.90 \mathrm{Cr}-0.48 \mathrm{Ni}-0.69$ & 0.9996286 \\
\hline & $Z n=-38.22+1.07 C d-0.31 F+0.14 B$ & 0.9999672 \\
\hline & $\mathrm{Cu}=28.41-0.92 \mathrm{Na}+0.38 \mathrm{~A} \%+0.08 \mathrm{Ni}$ & 1.0000000 \\
\hline & $\mathrm{Ni}=3.96-0.94$ Clay $\%+0.11 \mathrm{Ca}+0.02 \mathrm{TP}$ & 1.0000000 \\
\hline & $\mathrm{Cr}=43.11+0.98 \mathrm{Fe}-0.18 \mathrm{~F}-0.16 \mathrm{Sand} \%$ & 0.9999997 \\
\hline & $\mathrm{Pb}=1.59+0.79 \mathrm{Na}+0.57 \mathrm{Zn}-0.14 \mathrm{Mg}$ & 0.9999990 \\
\hline & $\mathrm{Cd}=2.00+1.69 \mathrm{Li}-0.77 \mathrm{IP}-0.03 \mathrm{Fe}$ & 0.9999995 \\
\hline \multirow[t]{8}{*}{ Dekhila } & $\mathrm{Fe}=12302.6-1.08$ Sand $\%+0.34 \mathrm{Ni}-0.11 \mathrm{SO} 4$ & 0.9999345 \\
\hline & $\mathrm{Mn}=-30.65+1.28 \mathrm{Fe}-0.34 \mathrm{~Pb}+0.11 \mathrm{SO} 4$ & 0.9999979 \\
\hline & $\mathrm{Zn}=-95.73+0.56 \mathrm{Mean}+0.43 \mathrm{~Pb}+0.13 \mathrm{TSiO} \%$ & 0.9999788 \\
\hline & $\mathrm{Cu}=42.63-0.93 \mathrm{~F}+0.54 \mathrm{Cr}+0.19 \mathrm{Cd}$ & 0.9989686 \\
\hline & $\mathrm{Ni}=583.4-1.19 \mathrm{Cl}+1.02 \mathrm{~A} \%+0.73$ Sand $\%$ & 0.9999819 \\
\hline & $\mathrm{Cr}$ & not significant \\
\hline & $\mathrm{Pb}=5.38+1.27 \mathrm{Zn}-0.66 \mathrm{OP}+0.13 \mathrm{Cr}$ & 0.9999796 \\
\hline & $\mathrm{Cd}=-1.0+0.91 \mathrm{Ca}+0.19 \mathrm{Cu}+0.08 \mathrm{Cr}$ & 0.9999981 \\
\hline \multirow[t]{8}{*}{ Western } & $\mathrm{Fe}=24718.2-1.01 \mathrm{~K}+1.11 \mathrm{~F}-0.73 \mathrm{Zn}-0.14$ Silt \% & 0.9999497 \\
\hline & $\mathrm{Mn}=117.56-0.68 \mathrm{Cu}+0.57 \mathrm{Mean}+0.41 \mathrm{Fe}+0.14 \mathrm{IP}$ & 0.9999757 \\
\hline & $Z n=-148.1+0.14 \mathrm{Na}+0.84 \mathrm{Tp}-0.39 \mathrm{~B}-0.07 \mathrm{Cr}$ & 0.99999963 \\
\hline & $\mathrm{Cu}=702.0-0.97 \mathrm{Mn}+0.71$ Mean $+0.43 \mathrm{Li}+0.29$ Sorting & 0.99998544 \\
\hline & $\mathrm{Ni}=-245.1+0.97 \mathrm{IP}+0.50 \mathrm{Mg}+0.26$ Sorting $+0.11 \mathrm{~A} \%$ & 0.99999963 \\
\hline & $\mathrm{Cr}=-226.1+0.92 \mathrm{Cd}+0.20 \mathrm{Mn}-0.10 \mathrm{Cl}+0.05 \mathrm{Cu}$ & 0.99999998 \\
\hline & $\mathrm{Pb}=263.2-0.54 \mathrm{~B}+0.48 \mathrm{Cr}-0.54 \mathrm{Li}-0.16 \mathrm{Zn}$ & 0.99999976 \\
\hline & $\mathrm{Cd}=12.5+1.08 \mathrm{Cr}-0.22 \mathrm{Mn}+0.11 \mathrm{C}-0.05 \mathrm{Cu}$ & 0.99999998 \\
\hline \multirow[t]{8}{*}{ Dameitta } & $\mathrm{Fe}=9773.0+0.75 \mathrm{Cr}+0.59 \mathrm{TSiO} \%$ & 0.99511927 \\
\hline & $\mathrm{Mn}=518.2+0.87 \mathrm{OP}+0.20 \mathrm{Ca}-0.10$ Clay $\%$ & 0.99999726 \\
\hline & $Z n=320.1+0.76 K-0.77 I P+0.62 A \%$ & 0.99997148 \\
\hline & $\mathrm{Cu}=22.3+0.96 \mathrm{Cd}+0.41 \mathrm{Cl}-0.25$ Silt $\%$ & 0.99996917 \\
\hline & $\mathrm{Ni}$ & not significant \\
\hline & $\mathrm{Cr}=368.5-1.23 \mathrm{Mean}+0.62 \mathrm{Mn}+0.10 \mathrm{~F}$ & 0.99999789 \\
\hline & $\mathrm{Pb}=31.4+1.08 \mathrm{Cd}-0.14 \mathrm{~A} \%-0.02 \mathrm{~F}$ & 1 \\
\hline & $C d=-2.12+0.93 \mathrm{~Pb}+0.13 \mathrm{~A} \%+0.02 \mathrm{~F}$ & 1 \\
\hline \multirow[t]{8}{*}{ Port Said } & $\mathrm{Fe}=15733.2+1.08 \mathrm{Slt} \%-0.0 .09 \mathrm{Ca}-0.06 \mathrm{Li}$ & 0.99999579 \\
\hline & $M n=1521.3-1.10$ Sand $\%-0.19$ SO4 -0.10 Sorting & 0.99999988 \\
\hline & $Z n=-25.0+0.96 \mathrm{Cu}+0.16 \mathrm{Fe}-0.06$ Clay $\%$ & 0.99999972 \\
\hline & $\mathrm{Cu}=16.9+1.04 \mathrm{Zn}-0.16 \mathrm{Fe}+0.07$ Clay $\%$ & 0.9999997 \\
\hline & $\mathrm{Ni}=73.4+1.13$ Silt $\%-0.31$ SO4 + 0.06 OP & 0.99999999 \\
\hline & $\mathrm{Cr}=-109.3+0.77 \mathrm{Na}+0.49 \mathrm{~B}-0.17$ Mean & 0.99992905 \\
\hline & $\mathrm{Pb}=5.27+1.27 \mathrm{Cu}-0.60$ Mean $+0.11 \mathrm{Na}$ & 0.99999901 \\
\hline & $C d=0.29+0.93 K+0.22 O P+0.13$ Sand $\%$ & 0.99999847 \\
\hline
\end{tabular}


The cluster of heavy metals grouping and the geochemical parameters analyses also demonstrate the great coordination of these among themselves and with other parameters in each harbor (Fig. 2). The main processes affecting the distribution of heavy metals in sediments are dispersion, precipitation and sedimentation and chemical reactions (Amankwaa et al. 2021).

Principle component analysis (PCA) is applied to heavy metals and geochemical results to identify potential factors and sources of pollutants in sediments from the studied harbors (Amankwaa et al. 2021). Fig. 3 demonstrates loading factors for the various studied parameters including heavy metals to sediments in the harbors examined after Varimax rotation. The obtained PCs explain the different percentages of each harbor, reflecting the difference in sediment properties and the contributions of different heavy metals. In most harbors, the results identified two PCs of eigenvalues greater than 1 , with the exception of Western Harbor displaying three PCs. About 73.45, 80.52, 86.07, 76.58 and $78.25 \%$ of the total variance in the sediments data sets represent the Sidi Krir, Dekhila, Western, Damietta and Port Said harbors respectively.

Box Whisker plots for the various detected heavy metals ( $\mathrm{Fe}, \mathrm{Mn}, \mathrm{Zn}, \mathrm{Cu}, \mathrm{Ni}, \mathrm{Cr}, \mathrm{Pb}$ and $\mathrm{Cd}$ ) in the sediments of the investigated harbors are represented (Fig. 4). However, the box represents the minimum $\left(Q_{0}\right.$ or $0 \%$, lowest data point excluding any outliers), maximum $\left(Q_{4}\right.$ or $100 \%$, highest data point excluding any outliers), Median $\left(\mathrm{Q}_{2}\right.$ or $50 \%$, the middle value of the dataset of each heavy metal. First quartile $\left(\mathrm{Q}_{1}\right.$ or $25 \%$, the lower quartile) is the median of the lower half of the dataset. Third quartile $\left(\mathrm{Q}_{3}\right.$ or $75 \%$, the upper quartile) is the median of the upper half of the dataset. Box Whisker plot for Sdi Krir Harbor shows great variability in Fe, Mn, Zn, and Cu contents. Amongst the studied heavy metals, Fe concentration varies greatly along the sediments of Sidi Krir, Dekhila, and Western harbors.

\section{Pollution and ecological indices}

\section{Enrichment factor (EF)}

The enrichment factor using the median background of the studied heavy metals in each harbor values gives minimal enrichment for all the determined elements. ( $E F<2$; Khalil et al. 2016).

\section{Geo-accumulation index $\left(I_{\text {geo }}\right)$}

Almost all harbors examined show that $100 \%$ of their stations are uncontaminated by all examined heavy metals $\left(I_{\text {geo }} \leq 0\right)$, except for $\mathrm{Cd}(\mathrm{Table} 6)$. Cd appears to contribute significantly to the sediment pollution in all stations in the studied harbors and $I_{\text {geoCd }}$ ranges from moderately to severe to severely polluted. High $I_{\text {geoCd }}$ values are observed in the sediments at Dekhila, Western, Damietta and Port Said harbors. 
Table 6

Overall pollution status using different risk indices in each of the studied harbors

\begin{tabular}{|c|c|c|c|c|c|c|c|}
\hline $\begin{array}{l}\text { Risk } \\
\text { indices }\end{array}$ & $\begin{array}{l}\text { Sidi } \\
\text { Krir }\end{array}$ & Dekhila & Western & Dameitta & $\begin{array}{l}\text { Port } \\
\text { Said }\end{array}$ & Most polluted station & Overall pollution status \\
\hline$E F_{F e}$ & $\begin{array}{l}0.35- \\
1.00\end{array}$ & $0.40-1.00$ & $\begin{array}{l}0.47- \\
0.95\end{array}$ & $\begin{array}{l}0.92- \\
1.00\end{array}$ & $\begin{array}{l}0.79- \\
1.00\end{array}$ & & No enrichment \\
\hline$E F_{M n}$ & $\begin{array}{l}0.13- \\
1.00\end{array}$ & $0.36-1.00$ & $\begin{array}{l}0.48- \\
0.99\end{array}$ & $\begin{array}{l}0.39- \\
1.00\end{array}$ & $\begin{array}{l}0.27- \\
1.00\end{array}$ & & No enrichment \\
\hline$E F_{Z n}$ & $\begin{array}{l}0.09- \\
1.00\end{array}$ & $0.44-1.00$ & $\begin{array}{l}0.29- \\
0.91\end{array}$ & $\begin{array}{l}0.76- \\
1.00\end{array}$ & $\begin{array}{l}0.32- \\
1.00\end{array}$ & & No enrichment \\
\hline$E F_{C u}$ & $\begin{array}{l}0.17- \\
1.00\end{array}$ & $0.00-1.00$ & $\begin{array}{l}0.41- \\
0.94\end{array}$ & $\begin{array}{l}0.73- \\
1.00\end{array}$ & $\begin{array}{l}0.07- \\
1.00\end{array}$ & & No enrichment \\
\hline$E F_{N i}$ & $\begin{array}{l}0.81- \\
1.00\end{array}$ & $0.06-1.00$ & $\begin{array}{l}0.43- \\
0.89\end{array}$ & $\begin{array}{l}0.64- \\
1.00\end{array}$ & $\begin{array}{l}0.30- \\
1.00\end{array}$ & & No enrichment \\
\hline$E F_{C r}$ & $\begin{array}{l}0.82- \\
1.00\end{array}$ & $0.09-1.00$ & $\begin{array}{l}0.03- \\
0.84\end{array}$ & $\begin{array}{l}0.84- \\
1.00\end{array}$ & $\begin{array}{l}0.32- \\
1.00\end{array}$ & & No enrichment \\
\hline$E F_{P b}$ & $\begin{array}{l}0.16- \\
1.00\end{array}$ & $0.14-1.00$ & $\begin{array}{l}0.08- \\
0.71\end{array}$ & $\begin{array}{l}0.52- \\
1.00\end{array}$ & $\begin{array}{l}0.12- \\
1.00\end{array}$ & & No enrichment \\
\hline$E F_{C d}$ & $\begin{array}{l}0.57- \\
1.00\end{array}$ & $0.26-1.00$ & $\begin{array}{l}0.41- \\
0.89\end{array}$ & $\begin{array}{l}0.30- \\
1.00\end{array}$ & $\begin{array}{l}0.43- \\
1.00\end{array}$ & & No enrichment \\
\hline$I_{\text {geo } \mathrm{Fe}}$ & -ve & -ve & -ve & -ve & -ve & & Unpolluted \\
\hline$I_{\text {geo } \mathrm{Mn}}$ & -ve & -ve & -ve & -ve-0.25 & $-v e-0.31$ & Stations $20,22,24$, and 26 & Unpolluted to moderately polluted \\
\hline$I_{g e o} \mathrm{Zn}$ & -ve & -ve & -ve-0.61 & -ve & -ve & Station $11-14$, and 16 & Unpolluted to moderately polluted \\
\hline$I_{g e o} \mathrm{Cu}$ & -ve & -ve & -ve-3.08 & -ve & -ve & Station 11,13 and 14 & Unpolluted to strongly polluted \\
\hline$I_{\text {geo } \mathrm{Ni}}$ & -ve & -ve-1.46 & -ve & $\begin{array}{l}0.76- \\
1.23\end{array}$ & $\begin{array}{l}0.03- \\
1.01\end{array}$ & Stations 7, and 17- 26 & Unpolluted to moderately polluted \\
\hline$I_{g e o} \mathrm{Cr}$ & -ve & -ve & -ve-1.86 & -ve & $-v e-0.22$ & Station 16 and 26 & Unpolluted to moderately polluted \\
\hline$I_{\text {geo } P b}$ & -ve & -ve-0.10 & -ve-2.44 & -ve-2.22 & -ve-0.74 & $\begin{array}{l}\text { Stations } 10,12,14,16,18, \\
22 \text { and } 23\end{array}$ & Unpolluted to moderately polluted \\
\hline$I_{g e o ~ C d}$ & $\begin{array}{l}2.69- \\
3.72\end{array}$ & $3.14-4.47$ & $\begin{array}{l}3.82- \\
7.06\end{array}$ & $\begin{array}{l}2.23- \\
5.32\end{array}$ & $\begin{array}{l}2.74- \\
3.90\end{array}$ & All stations & $\begin{array}{l}\text { Moderately to strongly polluted to Extremely } \\
\text { polluted }\end{array}$ \\
\hline$C F_{F e}$ & $\begin{array}{l}0.00- \\
0.01\end{array}$ & $0.15-0.29$ & $\begin{array}{l}0.18- \\
0.32\end{array}$ & $\begin{array}{l}0.48- \\
0.51\end{array}$ & $\begin{array}{l}0.43- \\
0.50\end{array}$ & All stations & No contamination \\
\hline$C F_{M n}$ & $\begin{array}{l}0.00- \\
0.05\end{array}$ & $0.20-0.38$ & $\begin{array}{l}0.29- \\
0.49\end{array}$ & $\begin{array}{l}0.77- \\
1.78\end{array}$ & $\begin{array}{l}0.85- \\
1.86\end{array}$ & $\begin{array}{l}\text { Stations } 17-18,20-24 \text {, and } \\
26\end{array}$ & No to moderate contamination \\
\hline$C F_{Z n}$ & $\begin{array}{l}0.03- \\
0.45\end{array}$ & $0.45-1.44$ & $\begin{array}{l}1.05- \\
2.29\end{array}$ & $\begin{array}{l}0.69- \\
1.06\end{array}$ & $\begin{array}{l}0.50- \\
1.09\end{array}$ & $\begin{array}{l}\text { Stations } 8,10-16,18, \text { and } \\
23\end{array}$ & No to moderate contamination \\
\hline$C F_{C u}$ & $\begin{array}{l}0.29- \\
1.13\end{array}$ & $0.04-0.63$ & $\begin{array}{l}0.95- \\
12.67\end{array}$ & $\begin{array}{l}0.41- \\
0.72\end{array}$ & $\begin{array}{l}0.09- \\
0.77\end{array}$ & Stations 11 & No to very high contamination \\
\hline$C F_{N i}$ & $\begin{array}{l}0.04- \\
0.06\end{array}$ & $0.04-2.75$ & $\begin{array}{l}0.05- \\
0.94\end{array}$ & $\begin{array}{l}1.70- \\
2.34\end{array}$ & $\begin{array}{l}1.02- \\
2.01\end{array}$ & $\begin{array}{l}\text { Stations } 7,18,20,21 \text { and } \\
26\end{array}$ & Moderate contamination \\
\hline$C F_{C r}$ & $\begin{array}{l}0.035- \\
0.04\end{array}$ & $0.04-0.46$ & $\begin{array}{l}0.04- \\
5.45\end{array}$ & $\begin{array}{l}0.79- \\
0.98\end{array}$ & $\begin{array}{l}0.74- \\
1 . .75\end{array}$ & $\begin{array}{l}\text { Station } 16,22-23 \text {, and } 25- \\
26\end{array}$ & No to very high contamination \\
\hline$C F_{P b}$ & $\begin{array}{l}0.27- \\
0.92\end{array}$ & $0.33-2.06$ & $\begin{array}{l}1.03- \\
10.39\end{array}$ & $\begin{array}{l}0.68- \\
8.92\end{array}$ & $\begin{array}{l}0.27- \\
3.21\end{array}$ & $\begin{array}{l}\text { Station } 8,10-16,18 \text {, and } \\
22-23\end{array}$ & No to very high contamination \\
\hline$C F_{C d}$ & $\begin{array}{l}9.65- \\
19.79\end{array}$ & $\begin{array}{l}13.21- \\
33.34\end{array}$ & $\begin{array}{l}13.21- \\
199.90\end{array}$ & $\begin{array}{l}7.06- \\
59.75\end{array}$ & $\begin{array}{l}10.00- \\
22.33\end{array}$ & All stations & very high contamination \\
\hline$C_{d}$ & $\begin{array}{l}10.82- \\
21.90\end{array}$ & $\begin{array}{l}15.04- \\
35.88\end{array}$ & $\begin{array}{l}33.92- \\
219.23\end{array}$ & $\begin{array}{l}12.79- \\
75.03\end{array}$ & $\begin{array}{l}14.44- \\
31.92\end{array}$ & All stations & $\begin{array}{l}\text { moderate dgree to very high degree of } \\
\text { contamination }\end{array}$ \\
\hline$m c_{d}$ & $\begin{array}{l}1.35- \\
2.74\end{array}$ & $1.88-4.48$ & $\begin{array}{l}4.24- \\
27.40\end{array}$ & $\begin{array}{l}1.60- \\
9.38\end{array}$ & $\begin{array}{l}1.80- \\
3.99\end{array}$ & $\begin{array}{l}\text { Stations } 7-16,17-18,19-24 \text {, } \\
\text { and } 26\end{array}$ & $\begin{array}{l}\text { low degree of contamination to extremely high } \\
\text { degree of contamination }\end{array}$ \\
\hline PLI & $\begin{array}{l}0.09- \\
0.19\end{array}$ & $0.30-0.88$ & $\begin{array}{l}0.89- \\
1.86\end{array}$ & $\begin{array}{l}0.98- \\
2.12\end{array}$ & $\begin{array}{l}0.70- \\
1.59\end{array}$ & Station 18 & Unpolluted to Heavily polluted \\
\hline PLIs & 0.13 & 0.54 & 1.19 & 1.27 & 1.24 & $\begin{array}{l}\text { Western, Damietta, and } \\
\text { Port Said }\end{array}$ & No to progressive deterioration \\
\hline
\end{tabular}




\begin{tabular}{|c|c|c|c|c|c|c|c|}
\hline $\begin{array}{l}\text { Risk } \\
\text { indices }\end{array}$ & $\begin{array}{l}\text { Sidi } \\
\text { Krir }\end{array}$ & Dekhila & Western & Dameitta & $\begin{array}{l}\text { Port } \\
\text { Said }\end{array}$ & Most polluted station & Overall pollution status \\
\hline$R I$ & $\begin{array}{l}297.8- \\
963.9\end{array}$ & $\begin{array}{l}234.6- \\
1852.9\end{array}$ & $\begin{array}{l}411.9- \\
6054.1\end{array}$ & $\begin{array}{l}234.6- \\
1852.9\end{array}$ & $\begin{array}{l}269.4- \\
466.8\end{array}$ & Station 15 & High to very high risk \\
\hline$T R I_{Z n}$ & $\begin{array}{l}0.02- \\
0.36\end{array}$ & $0.36-1.15$ & $\begin{array}{l}0.84- \\
1.82\end{array}$ & $\begin{array}{l}0.55- \\
0.84\end{array}$ & $\begin{array}{l}0.40- \\
0.87\end{array}$ & Station 13 & No toxic risk \\
\hline$T R I_{C u}$ & $\begin{array}{l}0.77- \\
3.04\end{array}$ & $0.12-1.68$ & $\begin{array}{l}2.55- \\
34.04\end{array}$ & $\begin{array}{l}1.11- \\
1.94\end{array}$ & $\begin{array}{l}0.25- \\
2.08\end{array}$ & Station 11 & Very high toxic risk \\
\hline$T R I_{N i}$ & $\begin{array}{l}0.15- \\
0.20\end{array}$ & $0.16-9.78$ & $\begin{array}{l}0.18- \\
3.36\end{array}$ & $\begin{array}{l}6.04- \\
8.32\end{array}$ & $\begin{array}{l}3.64- \\
7.15\end{array}$ & Station 7 & Low toxic risk \\
\hline $\mathrm{TRI}_{\mathrm{Cr}}$ & $\begin{array}{l}0.05- \\
0.06\end{array}$ & $0.06-0.66$ & $\begin{array}{l}0.06- \\
7.75\end{array}$ & $\begin{array}{l}1.13- \\
1.39\end{array}$ & $\begin{array}{l}1.05- \\
2.48\end{array}$ & Station 16 & Low toxic risk \\
\hline$T R I_{P b}$ & $\begin{array}{l}0.08- \\
0.28\end{array}$ & $0.10-0.62$ & $\begin{array}{l}0.31- \\
3.15\end{array}$ & $\begin{array}{l}0.21- \\
2.70\end{array}$ & $\begin{array}{l}0.08- \\
0.97\end{array}$ & Station 16 & No toxic risk \\
\hline$T R I_{C d}$ & $\begin{array}{l}1.73- \\
3.55\end{array}$ & $2.37-5.98$ & $\begin{array}{l}3.79- \\
35.84\end{array}$ & $\begin{array}{l}1.27- \\
10.71\end{array}$ & $\begin{array}{l}1.79- \\
4.00\end{array}$ & Station 16 & Very high toxic risk \\
\hline$\sum T R I$ & $\begin{array}{l}2.93- \\
6.06\end{array}$ & $\begin{array}{l}3.53- \\
15.59\end{array}$ & $\begin{array}{l}10.98- \\
49.60\end{array}$ & $\begin{array}{l}10.78- \\
23.48\end{array}$ & $\begin{array}{l}7.93- \\
15.76\end{array}$ & $\begin{array}{l}\text { All stations, except } \\
\text { stations 2-3, and 5-6 }\end{array}$ & No toxic risk to very high toxic \\
\hline TUs & $\begin{array}{l}0.76- \\
1.52\end{array}$ & $1.02-6.22$ & $\begin{array}{l}3.47- \\
13.20\end{array}$ & $\begin{array}{l}4.62- \\
8.13\end{array}$ & $\begin{array}{l}3.27- \\
6.15\end{array}$ & $\begin{array}{l}\text { Stations } 7,11,13,14,16- \\
24 \text { and } 26\end{array}$ & $\begin{array}{l}\text { No toxic risk to more than moderate toxic } \\
\text { ecosystem }\end{array}$ \\
\hline$m-E R M-Q$ & $\begin{array}{l}0.07- \\
0.13\end{array}$ & $0.09-0.92$ & $\begin{array}{l}0.29- \\
1.04\end{array}$ & $\begin{array}{l}0.63- \\
0.96\end{array}$ & $\begin{array}{l}0.42- \\
0.77\end{array}$ & Station 16 & Most stations are of $21 \%$ being biotoxic \\
\hline$m-P E L-Q$ & $\begin{array}{l}0.12- \\
0.25\end{array}$ & $0.17-0.92$ & $\begin{array}{l}0.57- \\
2.20\end{array}$ & $\begin{array}{l}0.70- \\
1.27\end{array}$ & $\begin{array}{l}0.50- \\
0.95\end{array}$ & Station 16 & Rang from $9-21 \%$ being bio toxic \\
\hline$H Q_{\text {sedZn }}$ & $\begin{array}{l}0.03- \\
0.46\end{array}$ & $0.46-1.48$ & $\begin{array}{l}1.08- \\
2.34\end{array}$ & $\begin{array}{l}0.71- \\
1.08\end{array}$ & $\begin{array}{l}0.51- \\
1.12\end{array}$ & Station 13 & No to moderately hazards \\
\hline$H Q_{\text {sedCu}}$ & $\begin{array}{l}1.07- \\
4.24\end{array}$ & $0.17-.2 .34$ & $\begin{array}{l}3.55- \\
47.43\end{array}$ & $\begin{array}{l}1.55- \\
2.71\end{array}$ & $\begin{array}{l}0.35- \\
2.90\end{array}$ & Station 11 & Potentail to very high hazards \\
\hline$H Q_{s e d N i}$ & $\begin{array}{l}0.20- \\
0.27\end{array}$ & $\begin{array}{l}0.21- \\
12.96\end{array}$ & $\begin{array}{l}0.24- \\
4.45\end{array}$ & $\begin{array}{l}8.01- \\
11.03\end{array}$ & $\begin{array}{l}4.83- \\
9.48\end{array}$ & Station7 & Potentail to very high hazards \\
\hline$H Q_{\text {sedCr }}$ & $\begin{array}{l}0.07- \\
0.08\end{array}$ & $0.08-0.89$ & $\begin{array}{l}0.1- \\
10.42\end{array}$ & $\begin{array}{l}1.51- \\
1.87\end{array}$ & $\begin{array}{l}1.41- \\
3.34\end{array}$ & Station 16 & Potentail to high hazards \\
\hline$H Q_{s e d P b}$ & $\begin{array}{l}0.11- \\
0.38\end{array}$ & $0.14-0.85$ & $\begin{array}{l}0.42- \\
4.30\end{array}$ & $\begin{array}{l}0.28- \\
3.69\end{array}$ & $0.11-.33$ & Station 16 & Potentail to moderate hazards \\
\hline$H Q_{\text {sedCd }}$ & $\begin{array}{l}2.13- \\
4.37\end{array}$ & $2.91-7.36$ & $\begin{array}{l}4.66- \\
44.10\end{array}$ & $\begin{array}{l}1.56- \\
13.18\end{array}$ & $\begin{array}{l}2.21- \\
4.92\end{array}$ & Station 16 & Moderate to high hazards \\
\hline$m H Q_{s e d Z n}$ & $\begin{array}{l}0.21- \\
0.86\end{array}$ & $0.86-1.54$ & $\begin{array}{l}1.32- \\
1.94\end{array}$ & $\begin{array}{l}1.07- \\
1.32\end{array}$ & $\begin{array}{l}0.91- \\
1.34\end{array}$ & station 13 & No low to moderate severity of contamination \\
\hline$m H Q_{\text {sedCu }}$ & $\begin{array}{l}1.20- \\
2.39\end{array}$ & $0.47-1.77$ & $\begin{array}{l}2.18- \\
7.98\end{array}$ & $\begin{array}{l}1.44- \\
1.91\end{array}$ & $\begin{array}{l}0.69- \\
1.97\end{array}$ & station 11 & No to extreme severity of contamination \\
\hline$m H Q_{\text {sedNi }}$ & $\begin{array}{l}0.56- \\
0.65\end{array}$ & $0.58-4.53$ & $\begin{array}{l}0.62- \\
2.66\end{array}$ & $\begin{array}{l}3.56- \\
4.18\end{array}$ & $\begin{array}{l}2.76- \\
3.87\end{array}$ & station 7 & Very low to extreme severity of contamination \\
\hline$m H Q_{\text {sedCr }}$ & $\begin{array}{l}0.35- \\
0.38\end{array}$ & $0.38-1.26$ & $\begin{array}{l}0.39- \\
4.33\end{array}$ & $\begin{array}{l}1.65- \\
1.84\end{array}$ & $\begin{array}{l}1.59- \\
2.45\end{array}$ & Station 16 & No to extreme severity of contamination \\
\hline$m H Q_{\text {sedPb }}$ & $\begin{array}{l}0.39- \\
0.73\end{array}$ & $0.43-1.09$ & $\begin{array}{l}0.77- \\
2.45\end{array}$ & $\begin{array}{l}0.63- \\
2.27\end{array}$ & $\begin{array}{l}0.39- \\
1.36\end{array}$ & Station 16 & No to considerable severity of contamination \\
\hline$m H Q_{\text {sedCd }}$ & $\begin{array}{l}1.62- \\
2.32\end{array}$ & $1.89-3.01$ & $\begin{array}{l}2.39- \\
7.36\end{array}$ & $\begin{array}{l}1.38- \\
4.03\end{array}$ & $\begin{array}{l}1.65- \\
2.46\end{array}$ & Station 16 & Low to extreme severity of contamination \\
\hline
\end{tabular}

\section{Contamination factor ( CF ), contamination degree ( $\mathrm{Cd}$ ) and modified degree of contamination ( $\mathrm{mCd}$ )}

The $C F$ of all the heavy metals studied in the harbors examined reflects that Fe is the only heavy metal showing a low level of contamination $\left(C F_{F e}<1\right)$, while Cd shows the very high contamination $\left(C F_{C d}>6\right)$ (Table 6). Most of the Damietta (sties: 17-18 and 20-21; 80\% of sites) and Port Said (sites: $22-24$ and 26; 80\% of sites) harbors stations suffer moderately from Mn pollution ( $1<C F_{M n}<3$ ), while three other harbors examined have low Mn contamination ( $\left.C F_{M n}<1\right)$. Most the stations studied in the examined harbors give $C F_{Z n}$ values of low contamination level $\left(C F_{Z n}<1\right)$, except for Western Harbor sites showing moderate zinc contamination $\left(1<C F_{Z n}<3\right)$. Half of Western Harbor sites have moderate $C u$ contamination (sites $13-15 ; 1<C F_{C u}<3$ ), while site 11 shows the highest percentage of $\mathrm{Cu}$ contamination $\left(\mathrm{CF}_{\mathrm{Cu}}>6\right)$ among the sites examined. Almost of the stations in inspected harbors have low Ni contamination $\left(\mathrm{CF}_{\mathrm{Ni}}<1\right)$ with the exception of site 7 in Dekhila and sites 17-21 in Damietta (100\% of sites) and sites $22-24$ and 26 in Port Said harbor (80\% of sites) which show medium Ni pollution (1< $C F_{N i}<3$ ). Almost all harbor stations give a low degree of $\mathrm{Cr}$ contamination $\left(C F_{C r}<1\right)$, except for station 16 (Western Harbor), and stations $22,23,25$ and 26 
(Port Said) are affected by moderate Cr pollution $\left(1<C F_{C r}<3\right)$. Western Harbor is the most Pb contaminated site, however, half of the sites (sites: 23,14 and 16$)$ show $C_{C_{u}}>6$, along with station 18 (Damietta Harbor), while the other sites range from low to $\mathrm{Pb}$ contamination. The $C_{d}$ and $m C_{d}$ values reflect that the harbors range from low to very high pollution areas. The $C_{d}$ values are taken in descending order for Western Harbor (33.9-219.0)> Damietta Harbor (12.875.0)> Dekhila (15.0-35.9)> Port Said (14.4-31.9.2)> Sidi Krir (10.8-21.9). The $m C_{d}$ values are taken in descending order: Western Harbor (4.2-27.4)> Damietta Harbor (1.6-9.4)> Dekhila (1.9-4.5)> Port Said (1.8-4.0)> Sidi Krir (1.4-2.7).

\section{Pollution load index (PLI)}

The PLI values are calculated for stations at each harbor and for each harbor zone (Ganugapenta et al. 2018). The $P L /$ values range from unpolluted ( $<0.7)$ especially along Sidi Krir and Dekhila to heavily polluted (<3) at Damietta Harbor (St 18); Fig. 5) The PL/for the zone gives the decreasing order: Damietta (1.27) > Port Said (1.24)> Western (1.19) > Dekhila harbors (0.54)> Sidi Krir (0.13) (Table 6 and Fig. 5 ), pointing out that the Western, Damietta and Port Said harbors are the most affected by heavy metal areas along the other harbors that were examined (exceed the baseline of pollutants $>1)($ Goher et al. 2014).

\section{Toxic risk index (TRI ) and integrated TRI ( $\sum$ TRI)}

The high $T R I_{C u}, T R I_{N i}$ and $T R I_{C d}$ values distinguished in the investigated harbors refer to the industrial and other anthropogenic sources, especially in Western and Damietta harbors (Table 6 and Fig. 5). It was reported that $\mathrm{Cu}$, Ni and Cd are obtained from anthropogenic activities (Al Naggar et al. 2018). Almost all the stations along the studied harbors range from low $\left(\sum T R K 5\right)$ to very high toxic ( $\left.\sum T R \gg 20\right)$ (Table 6 and Fig. 5). The high $\sum T R /$ values recorded in Western, Damietta and Port Said harbors reflect that these harbors are of considerable and very high toxic risk.

\section{Toxic units (TUs ) and sum of toxic units ( $\sum$ TUs)}

The TUs and $\sum$ TUs of each heavy metal and studied harbor are illustrated (Fig. 5). Most of the studied sites (sites 7, 11, 13, 14, 16-24 and 26) show that $\sum T$ S exceed 4 amount for the moderate toxicity, i.e. significant mortality can be observed (Zhang et al. 2016). Higher values of $T U_{N i}($ sites 7 , and $17-26)$ and $T U_{C u}$ (site 11) along the investigated region may be associated with the significant environmental toxicity contribution due to the liquid hydrocarbons' sources and cargo activity (Yee 2010). The higher $T U_{C d}$ values shown for Damietta and Port Said harbors probably reflect the oil pollution from the shipping activities and oil refining and gas liquefaction and other petrochemical industrial projects (El-Asmar et al. 2014; Al Naggar et al. 2018).

\section{Mean ERM ( $m-E R M-Q)$ and mean PEL ( $m-P E L-Q)$ quotients}

Amongst the harbors studied, Sidi Krir shows the lowest quotient values of $m-E R M-Q(0.07-0.13)$ and $m-P E L-Q(0.12-0.25)$, representing $9-21 \%$ being bio toxic with least potential adverse effects marine on the environment (Table 6). Given the $m-E R M-Q$ values, most of the stations in the harbors examined have $21 \%$ of adverse biotoxic effects on the marine ecosystem, whereas, the high $m-P E L-Q$ quotients reflect that about $49 \%$ of the potential biotoxicity may occur in Damietta and Port Said harbors. The variability of biotoxicity from one harbor to another may be related to the sediment texture; i.e., the high sediment contamination with heavy metals especially in silty clay sediments as previously reported (Long et al. 2000). However, the highest $m-E R M-Q$ and $m-P E I-Q$ quotients are recorded in the harbors of lower carbonate and higher sand, silt and clay \% (Table 3).

\section{Sediment modified hazard quotient $\left(\mathrm{mHQ}_{\mathrm{sed}}\right)$}

According to the $m \mathrm{mQ}_{\text {sed }}$, Western Harbor is shown to be highly hazardous for contamination (2.5> $\left.m \mathrm{HQ} Q_{\text {sed }}>3\right)$ with values of $\mathrm{Cu}, \mathrm{Ni}$, and $\mathrm{Cd}(\mathrm{Table} 6)$. The harbors of Damietta and Port Said show severe Ni contamination $\left(m H Q_{s e d}>3.5\right)$ and for other metals it ranges from low $\left(m H Q_{s e d}<0.5\right)$ to moderate contamination $\left(1.5>m \mathrm{HQ}_{\text {sed }}>2\right)$.

\section{Sediment hazard quotients $\left(\mathrm{HQ}_{\mathrm{sed}}\right)$}

In Table 6, along the harbors studied, most stations in Western Harbor range from medium to high risk with $\mathrm{Cu}(3.5-47.4), \mathrm{Pb}(0.4-4.3)$ and $\mathrm{Cd}$ (4.7-44.1), except Cr which gives $H Q$ sed values (0.1-10.4) that ranges from potential to high risk. Stations in the harbors of Damietta $\left(H Q_{\text {sedNi; }}\right.$ 8.0-11.0) and Port Said $\left(H Q_{\text {sed }}\right.$ i 4.8-9.5) exhibit moderate Ni risks, while only station 7 at Dekhila Harbor gives high risk with $\mathrm{Ni}\left(H Q s_{e d N \mathrm{i}}=13.0\right)$.

\section{Human health risk assessment}

The $C D /$ values presented for specific heavy metals for children are higher than those for adults along the studied area due to the same consumption of heavy metals for child, lower exposure time and lower body weight resulting in higher $C D /$ values. For Fe, the chronic daily intake $\left(C D I_{F e}\right)$ of the child (5.3E-03- 5.1E-01, av. $2.9 \mathrm{E}-01 \mathrm{mg} / \mathrm{Kg}$-day) and adult (2.3E-04-2.2E-02, av. $1.2 \mathrm{E}-02 \mathrm{mg} / \mathrm{Kg}$-day) in the harbors studied. The $C D I_{F e}$ takes a child and adult in the order of harbors: Damietta (5.1E-01 and 2.2E-02, respectively)> Port Said (4.8E-01 and 2.1E-02, respectively) > Western (2.6E-01 and 1.1E-02, respectively)> Dekhila (2.4E-01 and $1.0 \mathrm{E}-02$, respectively) > Sidi Krir (5.3E-03 and 2.3E-04, respectively) considering that the chronic toxicity of oral sediment ingestion to adults in all harbors causes no hemosiderosis and cirrhosis symptoms (0.7-1.4 mg/Kg-day) (USEPA 2006). All other harbors ( $\left.C D I_{F e}\right)$ for adults appear lower than those reported in dietary intake and biochemical indices for adult (0.15-0.27 mg/Kg-day) (USEPA 2006). For Mn, the chronic daily intake (CDI ${ }_{\text {Mn }}$ of the child (4.6E-04-3.0E-02, av. 1.4E-02 mg/Kg-day) and adult (2.0E-05-1.3E-03, av. 6.2E-04 mg/Kg-day) in the harbors studied is less than tolerable upper intake level for adult age $\geq 19$ years (11 mg/Kg-day) (ATSDR 2012a). ( $\left.C D I_{Z n}\right)$ of children and adults is lower than those recorded for gastrointestinal symptoms $(0.16$ and $0.05 \mathrm{mg} / \mathrm{Kg}$-day) (ATSDR 2005a). For $\mathrm{Cu}, C D I_{C u}$ shows lower than reported for no-observed-adverse-effect level (NOAEL, $0.0272 \mathrm{mg} / \mathrm{Kg}$-day) and lowest-observed-adverse effect level (LOAEL, $0.0731 \mathrm{mg} / \mathrm{Kg}$-day) causing increased nausea vomiting, and/or abdominal pain. Based on the appropriate daily nickel dose recorded for food using a $70 \mathrm{Kg}$ body weight reference $(0.0024 \mathrm{mg} / \mathrm{Kg}$-day) (ATSDR $2005 \mathrm{~b})$, the $C D \mathrm{I}_{\mathrm{Ni}}$ harbors values have leaser values for $\mathrm{Ni}$ toxicity. $C D \mathrm{I}_{\mathrm{Cr}}$ for child and adult 
along the harbors also sets lower values than those reported for oral chromium (VI) compounds intermediate duration (MRL, $0.005 \mathrm{mg} / \mathrm{Kg}$-day) (ATSDR 2008). The $C D I_{P b}$ for children and adults along the harbors studied are of higher values than those reported for the Pb reference dose (RFD of tetraethyl lead, $1 \mathrm{X} 10^{-7} \mathrm{mg} / \mathrm{Kg}$-day) (ATSDR 2020) that may pose health risks. All $C D I_{P b}$ values for children (2.1E-04 - $1.9 \mathrm{E}-03 \mathrm{mg} / \mathrm{Kg}$-day) and adults (9.2E-06 - 8.2E-05 $\mathrm{mg} / \mathrm{Kg}$-day) belonging to the harbors examined have values lower than those specified for lead toxicity (ATSDR 2020). CDI Cd values for children (av. 1.2E-04 $\mathrm{mg} / \mathrm{Kg}$-day) and adults (av. 5.2E-06 mg/Kg-day) show lower amounts than those recorded for renal system toxicity symptoms (2.1E-03 mg/Kg-day) (ATSDR 2012c).

$H Q$ values of children are higher than those for adults and show amounts of less than 0.2 , reflecting no risk of ingestion and dermal contact with sediment (Fig. 6). THQ values appear approximately below unity except for the harbors of Western (2.6), Port Said (2.5), and Damietta (2.3). Non-carcinogenic hazard risk index $(H)$ for children and adults shows amounts more than unity and the harbors are said to be not polluted with heavy metals, except for children in the Western (3.2), Port Said (2.9), Damietta (2.6) harbors (Fig. 7). Non-carcinogenic hazard risk index (HI) values along the harbor take the order: Western> Port Said> Damietta> Dekhila> Sidi Krir.

CTR Ing and $C T R_{\text {Derm }}$ values for children and adults show values beyond 1.0E-04 (Figure 7). Also, TLCR values for children and adults indicate the nonuniformly high abundance of heavy metals in the harbors sediments that possibly cause adverse public health effects. This explores that it is necessary to monitor heavy metals involving many industries, agriculture, and wastewaters for exposure risks.

\section{Conclusions}

The impact of anthropogenic heavy metal pollution in the sediments of five economic harbors along Egyptian Mediterranean Sea, was evaluated using multivariate statistical analysis techniques and ecological indices $\left(E F, I_{\text {geo }}, C F, C_{d}, m C_{d}, P L I, R I, T R I, T U s, m P E L Q, m E R M Q, H Q_{s e d}\right.$ and $\left.m H Q_{s e d}\right)$ to investigate negative environmental impact as well as the geological and anthropogenic sources of heavy metals in the examined harbors. Sediment properties were identified by grain size, sorting, skwenes, Kurtosis, water content, besides their geochemistry by determining TOC \%, TCO $\%, \mathrm{TSiO}_{3} \%, \mathrm{TP}, \mathrm{IP}, \mathrm{OP}, \mathrm{Ca}, \mathrm{Mg}, \mathrm{Na}, \mathrm{K}, \mathrm{Li}$, $\mathrm{B}, \mathrm{SO}_{4}, \mathrm{Cl}$, and $\mathrm{F}$. The results reflected that the distribution of total organic carbon in the studied harbor sediments was strongly influenced by the amount of $\mathrm{CaCO}_{3}$.

Sediment quality guidelines ( $S Q G S$ ) indicated that most of the identified heavy metals ( $\mathrm{Cu}, \mathrm{Ni}, \mathrm{Cr}, \mathrm{Pb}$ and $\mathrm{Cd}$ ) in the studied harbors ranged between $T E L$ and $P E L$ values, except for average the $\mathrm{Ni}$ in the harbors of Dekhila and Port Said, which was more than ERM values and Cd contents which were relatively similar to the ERM. Heavy metals contamination was associated with the evacuation of wastewater from phosphate fertilizers and untreated industrial pollutants, along with shipping activities.

The statistical analyses reflected those sediments with smaller grain sizes (clay and silt) had a greater capacity to adsorb P and indicated the formation of fluorapatite $\left(\mathrm{Ca}_{5}\left(\mathrm{PO}_{4}\right)_{3} \mathrm{~F}\right)$. These analyses also referred to the formation of aragonite and high $\mathrm{Mg}$ calcite.

Amongst the ecological indices, contamination degree $\left(C_{d}\right)$ and modified degree of contamination $\left(m C_{d}\right)$ gave the descending order: Western Harbor> Damietta Harbor> Dekhila> Port Said> Sidi Krir. Given the values of median range effect quotient ( $m$-ERM-Q), most of the stations in the harbors examined had $21 \%$ of the adverse biotoxic effects on the marine ecosystem, while the levels of probable effect quotient ( $m-P E L-Q$ ) showed that about $49 \%$ of the potential biotoxicity was reflected in the harbors of Damietta and Port Said.

$H Q$ values of children were higher than those for adults and showed amounts of less than 0.2 , reflecting the lack of risk of ingestion and dermal contact with sediment. While, values of $T H Q$ were less than unity except for Western, Port Said and Damietta harbors which reflect expected pollution.

Therefore, it is critical to identify the differences in heavy metals in harbor sediments and their potential environment and public health risks, which allow the management makers to review, assess, manage and provide information, and make a better decision on environmental management of harbors.

\section{Declarations}

\section{Declaration of interest}

Declarations of interest: none

\section{Funding sources}

This research did not receive any specific grant from funding agencies in the public, commercial, or not-for-profit sectors.

\section{References}

1. Abdel-Halim AM, Aly-Eldeen MA (2016) Characteristics of Mediterranean Sea water in vicinity of Sidikerir Region, west of Alexandria, Egypt. Egypt J Aquat Res 42:133-140. https://doi.org/10.1016/j.ejar.2016.05.002

2. Anselm CD, Robinson RJ (1951) The spectrophotometric determination of fluoride in sea water. J Mar Res 10:204-214

3. APHA-AWWA-WPCF (1999) Standard methods for the examination of water and waste water, 20th edn. American Public Health Association), Washington, DC, USA 
4. Ashayeri NY, Keshavarzi B (2019) Geochemical characteristics, partitioning, quantitative source apportionment, and ecological and health risk of heavy metals in sediments and water: A case study in Shadegan Wetland, Iran. Mar Pollut Bull 149:110495. https://doi.org/10.1016/j.marpolbul.2019.110495

5. Aspila KI, Agemian H, Chau ASY (1976) A semi-automated method for the determination of nitrogen, organic and total phosphorus in sediments. Analyst 101:187-197

6. ATSDR (Agency for Toxic Substances and Disease Registry) (2008) Draft toxicological profile for nickel, U.S. Department of Health and Human Services, Public Health Service

7. ATSDR (Agency for Toxic Substances and Disease Registry) (2012c) Toxicological profile for cadmium, U.S. Department of Health and Human Services, Public Health Service

8. ATSDR (Agency for Toxic Substances and Disease Registry) (2005a) Toxicological profile for zinc, U.S. Department of Health and Human Services, Public Health Service

9. ATSDR (Agency for Toxic Substances and Disease Registry) (2020) Toxicological profile for lead, U.S. Department of Health and Human Services, Public Health Service

10. ATSDR (Agency for Toxic Substances and Disease Registry) (2012b) Toxicological profile for manganese, U.S. Department of Health and Human Services, Public Health Service

11. ATSDR (Agency for Toxic Substances and Disease Registry) (2012) Toxicological profile for chromium, U.S. Department of Health and Human Services, Public Health Service

12. ATSDR (Agency for Toxic Substances and Disease Registry) (2005b) Toxicological profile for nickel, U.S. Department of Health and Human Services, Public Health Service

13. Al Naggar Y, Khalil MS, Ghorab MA (2018) Environmental pollution by heavy metals in the aquatic ecosystems of Egypt. J Toxicol 3(1):555603. 10.19080/OAJT.2018.03.555603

14. Amankwaa G, Yin X, Zhang L, Huang W, Cao Y, Ni X, Gyimah E (2021) Spatial distribution and eco-environmental risk assessment of heavy metals in surface sediments from a crater lake (Bosomtwe/Bosumtwi). Environ Sci Pollut Res 28:19367-19380. 10.1007/s11356-020-12112-0

15. Bhardwaj R, Gupta A, Garg JK (2017) Evaluation of heavy metal contamination using environmetrics and indexing approach for River Yamuna, Delhi stretch, India. Water Sci 31(1):52-66. https://doi.org/10.1016/j.wsj.2017.02.002

16. Bhattacharya RK, Chatterjee ND, Dolui G (2016) Grain size characterization of instream sand deposition in controlled environment in river Kangsabati, West Bengal. Model Earth Syst Environ 2:118. DOI 10.1007/s40808-016-0173-z

17. Bingham FT (1982) Boron.. In: In: Page AL, Miller RH, Keeney DR (eds) Methods of Soil Analysis, Part 2. Chemical and Microbiological Properties, vol 9 , 2nd edn. SSSA, Madison, WI, USA, pp 431-447

18. Cherfi A, Cherfi M, Maache-Rezzoug Z, Rezzoug SA (2016) Risk assessment of heavy metals via consumption of vegetables collected from different supermarkets in La Rochelle, France. Environ Monit Assess 188(3):136. DOI 10.1007/s10661-016-5140-7

19. Deng M, Yang X, Dai X, Zhang Q, Malik A, Sadeghpour A (2020) Heavy metal pollution risk assessments and their transportation in sediment and overlay water for the typical Chinese reservoirs. Ecol Indic 112. DOI: 10.1016/j.ecolind.2020.106166

20. Duane DB (1964) Significance of skewness in recent sediments western Pamlico sound, North Carolina. J Sediment Petrol 27(1):3-27

21. El Barjy M, Maanan M, Maanan M, Salhi F, Tnoumi A, Zourarah B (2020) Contamination and environmental risk assessment of heavy metals in marine sediments from Tahaddart estuary (NW of Morocco). Hum Ecol Risk Assess 26(1):87-102. DOI: 10.1080/10807039.2018.1495056

22. El Nemr A, El-Said GF (2017) Heavy metals in sediment and molluscs from the Mediterranean Coast. Water Environ Res 89(3):195-210. DOl: $10.2175 / 106143016$ X14798353399458

23. El-Alfy MA, El-Amier YA, El-Eraky TE (2020) Land use/cover and eco-toxicity indices for identifying metal contamination in sediments of drains, Manzala Lake. Egypt Heliyon 6:e03177. https://doi.org/10.1016/j.heliyon.2020.e03177

24. El-Asmar HM, El-Kafrawy SB, Taha MMN (2014) Monitoring Coastal Changes along Damietta Promontory and the Barrier Beach toward Port Said East of the Nile Delta, Egypt. J Coast Res 30(5):993-1005. DOI: 10.2112/JCOASTRES-D-12-00112.1

25. El-Gharabawy SM, Shata MA, Ibrahim MS, El-Gammal MI, Draz SO (2011) Speciation of heavy metals in marine sediments from Damietta Harbor, Egypt. Egypt J Aquat Res 37(3):233-242

26. Elsagh A, Jalilian H, Aslshabestari MG (2021) Evaluation of heavy metal pollution in coastal sediments of Bandar Abbas, the Persian Gulf, Iran: Mercury pollution and environmental geochemical indices. Mar Pollut Bull 167:112314. DOI: 10.1016/j.marpolbul.2021.112314

27. EL-Said GF, Draz SEO, EL-Sadaawy MM, Moneer AA (2014) Sedimentology, geochemistry, pollution status and ecological risk assessment of some heavy metals in surficial sediments of an Egyptian lagoon connecting to the Mediterranean Sea. J Environ Sci Health A 49:1029-1044. DOI: $10.1080 / 10934529.2014 .894853$

28. El-Said GF, El Zokm GM, El Sayed AA, El Ashmawy AA, Shreadah MA (2020) Anomalous Fluctuation of Halogens in Relation to the Pollution Status along Lake Mariout, Egypt. J Chem 2020, Article ID 8102081:20. pages https://doi.org/10.1155/2020/8102081

29. El-Said GF, El-Sadaawy MM, Moneer AA (2010) Incorporation of fluoride and boron into surface sediments along the Egyptian Mediterranean coast. Egypt J Aquat Res 36(4):569-583

30. El-Said GF, El-Sadaawy MM, Moneer AA, Shaltout NA (2015) The effect of fluoride on the distribution of some minerals in the surface water of an Egyptian lagoon at the Mediterranean Sea. Egypt J Aquat Res 41(1):31-39. https://doi.org/10.1016/j.ejar.2015.02.004

31. El-Said GF, El-Sadaawy MM, Shaltout NA, Moneer AA (2021) Spatiotemporal distribution of some dissolved salts and minerals in Lake Edku connected to Mediterranean Sea: in relation to different pollutant inputs. Environ Monit Assess 193:155. DOI: 10.1007/s10661-021-08935-0

Page 17/25 
32. El-Said GF, Khalil MKh, Draz SEO (2016) Anomalous distribution of fluoride and phosphorus forms in surface sediments along eastern Egyptian Mediterranean Sea coast. Environ Sci Pollut Res 23:14240-14253. DOI 10.1007/s11356-016-6552-1

33. El-Sadaawy MM, El-Said GF, Sallam NA (2013) Bioavailability of heavy metals in fresh water Tilapia nilotica (Oreachromis niloticus Linnaeus, 1758): Potential risk to fishermen and consumers. J Environ Sci Health B 48:402-409. DOI: 10.1080/03601234.2013.742719

34. Enuneku A, Omoruyi O, Tongo I, Ogbomida E, Ogbeide O, Ezemonye L (2018) Evaluating the potential health risks of heavy metal pollution in sediment and selected benthic fauna of Benin River, Southern Nigeria. Appl Water Sci 8:224. https://doi.org/10.1007/s13201-018-0873-9

35. Folk RL (1974) Petrography of sedimentary rocks. Hemphill Publishing Company, Austin, Texas, p 182

36. Friedman GM (1962) On sorting coefficient and log normality of the grain size distribution of sandstones. J Geol 70:737-753

37. Ganugapenta S, Nadimikeri N, Chinnapolla SRRB, Ballari L, Madiga R, Nirmala K, Tella LP (2018) Assessment of heavy metal pollution from the sediment of Tupilipalem Coast, southeast coast of India. Int J Sediment Res 33(3):294-302. DOI: 10.1016/j.ijsrc.2018.02.004

38. Goher ME, Farhat HI, Abdo MH, Salem SG (2014) Metal pollution assessment in the surface sediment of Lake Nasser, Egypt. Egypt J Aquat Res 40:213224. https://doi.org/10.1016/j.ejar.2014.09.004

39. Hakanson L (1980) An ecological risk index for aquatic pollution control, a sedimentological approach. Water Res 14(8):975-1001. https://doi.org/10.1016/0043-1354(80)90143-8

40. Harlove DE, Aranovich L (2018) The Role of Halogens in Terrestrial and Extraterrestrial, Geochemical Processes, Surface, Crust, and Mantle, Springer Geochemistry, @ Springer International Publishing AG, Switzerland, 1030 pages

41. Heneash AMM (2015) Zooplankton composition and distribution in a stressed environment (El Dekhaila Harbour), South-Eastern Mediterranean Sea, Egypt. Inter J Adv Res Biol Sci 2(11):39-51

42. Ibrahim MIA, Mohamed LA, Mahmoud MG, Shaban KhS, Fahmy MA (2019) Potential ecological hazards assessment and prediction of sediment heavy metals pollution along the Gulf of Suez, Egypt. Egypt J Aquat Res 45:329-335. https://doi.org/10.1016/j.ejar.2019.12.003

43. Jeffery PG (1975) Chemical methods of rock analysis, 2nd edn. Pergamon Press, New York, NY, USA

44. Jin X, Wang S, Pang Y, Wu FC (2006) Phosphorus fractions and the effect of pH on the phosphorus release of the sediments from different trophic areas in Taihulake, China. Environ Pollut 139(3):288-295. https://doi.org/10.1016/j.envpol.2005.05.010

45. Johnbull O, Abbassi B, Zytner RG (2019) Risk assessment of heavy metals in soil based on the geographic information system-Kriging technique in Anka, Nigeria. Environ Eng Res 24(1):150-158. DOI: https://doi.org/10.4491/eer.2018.130

46. Kapanen G (2008) Phosphorus fractionation in lake sediments. Estonian J Ecol 57(4):244-255. doi: 10.3176/eco.2008.4.02

47. Khalil MKh, Draz SEO, El Zokm GM, El-Said GF (2016) Apportionment of geochemistry, texture's properties and risk assessment of some elements in surface sediments from Bardawil Lagoon, Egypt. Hum Ecol Risk Assess 22(3):775-791. https://doi.org/10.1080/10807039.2015.1107714

48. Kusin FM, Azani NNM, Hasan SNMS, Sulong NA (2018) Distribution of heavy metals and metalloid in surface sediments of heavily-mined area for bauxite ore in Pengerang, Malaysia and associated risk assessment. CATENA 165:454-464. https://doi.org/10.1016/j.catena.2018.02.029

49. Li J, Chen Y, Lu H, Zhai W (2021) Spatial distribution of heavy metal contamination and uncertainty-based human health risk in the aquatic environment using multivariate statistical method. Environ Sci Pollut Res 28:22804-22822. doi: 10.1007/s11356-020-12212-x

50. Liu B, Wang J, Xu M, Zhao L, Wang Z (2019) Spatial distribution, source apportionment and ecological risk assessment of heavy metals in the sediments of Haizhou Bay national ocean park, China. Mar Pollut Bull 149:110651. https://doi.org/10.1016/j.marpolbul.2019.110651

51. Liu J, Zhang J, Lu S, Zhang D, Tong Z, Yan Y, Hu B (2020) Interannual variation, ecological risk and human health risk of heavy metals in oyster-cultured sediments in the Maowei Estuary, China, from 2011 to 2018. Mar Pollut Bull 154:111039. DOI: 10.1016/j.marpolbul.2020.111039

52. Long ER, Field LJ, MacDonald DD (1998) Predicting toxicity in marine sediments with numerical sediment quality guidelines. Environ Toxicol Chem 17:714-727

53. Long ER, MacDonald DD, Severn CG, Hong CB (2000) Classifying probabilities of acute toxicity in marine sediments with empirically derived sediment quality guidelines. Environ Toxicol Chem 19(10):2598-2601

54. Loring DH, Rantala RTT (1992) Manual for the geochemical analysis of marine sediments and suspended particulate matter. Earth Sci Rev 32(4):235283. https://doi.org/10.1016/0012-8252(92)90001-A

55. MacDonald DD, Carr RS, Calder FD, Long ER, Ingersoll CG (1996) Development and evaluation of sediment quality guidelines for Florida coastal waters. Ecotoxicology 5:253-278

56. MacDonald DD, Ingersoll CG, Berger TA (2000) Development and evaluation of consensus-based sediment quality guidelines for freshwater ecosystems. Arch Environ Contam Toxicol 39:20-31

57. Masoud MS, El-Sarraf WM, Harfoush AA, El-Said GF (2004) Studies on fluoride-zirconium-alizarin red S reaction. Egypt Sci Mag 1:27-32

58. Molnia BF (1974) A rapid and accurate method for the analysis of calcium carbonate in small samples. J Sed Petrol 44(2):589-590. https://doi.org/10.1306/74D72A9F-2B21-11D7-8648000102C1865D

59. Müller G (1969) Index of geoaccumulation in sediments of the Rhine River. Geo Journal 2(3):108-118

60. Murphy J, Riley JP (1962) A modified single solution method for the determination of phosphate in natural waters. Anal Chem Acta 27:31-36

61. Omran EE (2016) Environmental modelling of heavy metals using pollution indices and multivariate techniques in the soils of Bahr El Baqar, Egypt. Model Earth Syst Environ 2:119. https://doi.org/10.1007/s40808-016-0178-7

62. Oregioni B, Aston SR (1984) Determination of selected trace metals in marine sediments by flame/flameless atomic absorption spectrophotometer. IAEA Monaco Laboratory Internal Report. Now cited in reference method in pollution studies No. 38. UNEP 
63. Pakzad HR, Pasandi M, Soleimani M, Kamali M (2014) Distribution and origin of heavy metals in the sand sediments in a sector of the Oman Sea (the Sistan and Baluchestan province, Iran). Quat Int 345:138-147. https://doi.org/10.1016/j.quaint.2014.03.031

64. Pederson F, Bjorestad E, Andersen HV, Kjolholt J, Poll C (1998) Characterization of sediments from Copenhagen Harbor by use of biotests. Water Sci Technol 37(6-7):233-240. https://doi.org/10.1016/S0273-1223(98)00203-0

65. Pikey OH, Morton RW, Luternauer J (1967) The carbonate fractions of beach and dune. Sedimentology 8(4):311-327. DOI:10.1111/J.136530911967.TB01330.X

66. Saad MAH, Beltagy Al, Mahmoud WM (2003) Total dissolved and particulate lead in the Western Harbor of Alexandria, a Mediterranean basin under stress. Mar Pollut Bull 47:52-58. DOI: 10.1016/S0025-326X(02)00470-8

67. Shen F, Mao L, Sun R, Du J, Tan Z, Ding M (2019) Contamination evaluation and source identification of heavy metals in the sediments from the Lishui River Watershed, Southern China. Int J Environ Res Public Health 16(3):336-350. doi: 10.3390/ijerph16030336

68. Smith SL, MacDonald DD, Keenleyside KA, Ingersoll CG, Field LJ (1996) A preliminary evaluation of sediment quality assessment values for freshwater ecosystems. J Great Lakes Res 22:624-638. https://doi.org/10.1016/S0380-1330(96)70985-1

69. Soliman NF, Nasr SM, Okbah MA (2015) Potential ecological risk of heavy metals in sediments from the Mediterranean coast, Egypt. J Environ Health Sci Eng 13:70. DOI 10.1186/s40201-015-0223-x

70. USEPA (United States Environmental Protection Agency) (2006) Provisional Peer Reviewed Toxicity Values (PPRTVs) for iron and compounds (CASRN 7439-89-6), Derivation of Subchronic and Chronic Oral RfDs. Superfund Health Risk Technical Support Center, National Center for Environmental Assessment, Office of Research and Development, U.S. Environmental Protection Agency. Cincinnati, OH 45268,9 September 2006.

71. USEPA (United States Environmental Protection Agency) (2012) Integrated Risk Information System of the US Environmental Protection Agency

72. USEPA (United States Environmental Protection Agency) (2011) Exposure Factors Handbook (2011) Edition (Final); United States Environmental Protection Agency: Washington, DC, USA. Available online: http://cfpub.epa.gov/ncea/risk/recordisplay.cfm?deid=236252 (accessed on 18 September 2019)

73. Wigley RL (1961) Bottom sediments of Georges Bank. J Sediment Res 31(2):165-188. https://doi.org/10.1306/74D70B2D-2B21-11D7$8648000102 \mathrm{C} 1865 \mathrm{D}$

74. Yang H, Sh C (2019) Sediment Grain-Size Characteristics and its Sources of Ten Wind-Water Coupled Erosion Tributaries (the Ten Kongduis) in the Upper Yellow River. Water 11:115. https://doi.org/10.3390/w11010115

75. Yee D (2010) Technical Data Report, Human Health Risk Assessment, Enbridge Northern Gateway Project. AMEC \& Environmental, Calgary, AL, USA

76. Zhang G, Bai J, Zhao Q, Lu Q, Jia J, Wen X (2016) Heavy metals in wetland soils along a wetland-forming chronosequence in the Yellow River Delta of China: Levels, sources and toxic risks. Ecol Indic 69:331-339. DOI: 10.1016/j.ecolind.2016.04.042

\section{Figures}



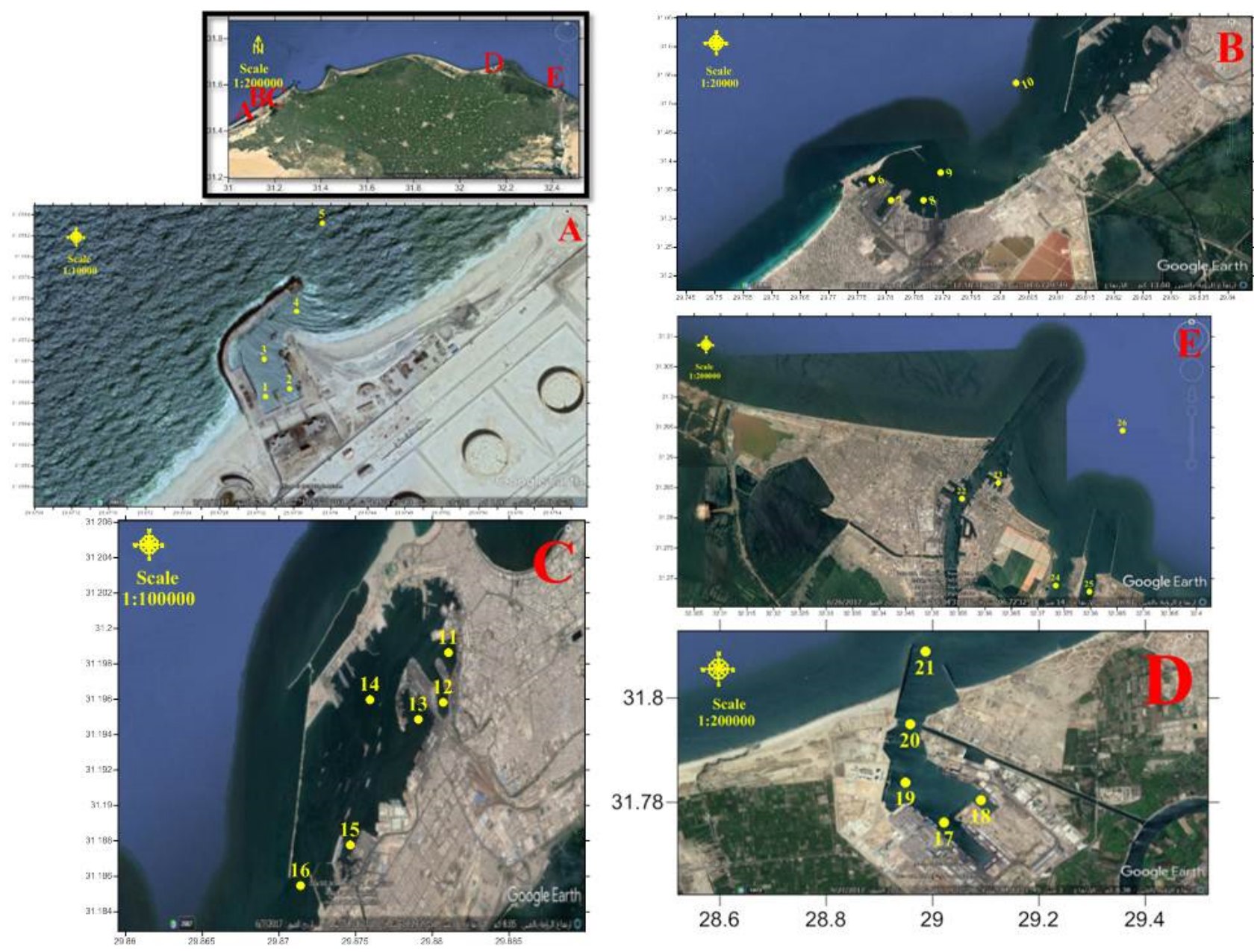

Figure 1

Sampling sites of the studied harbors 

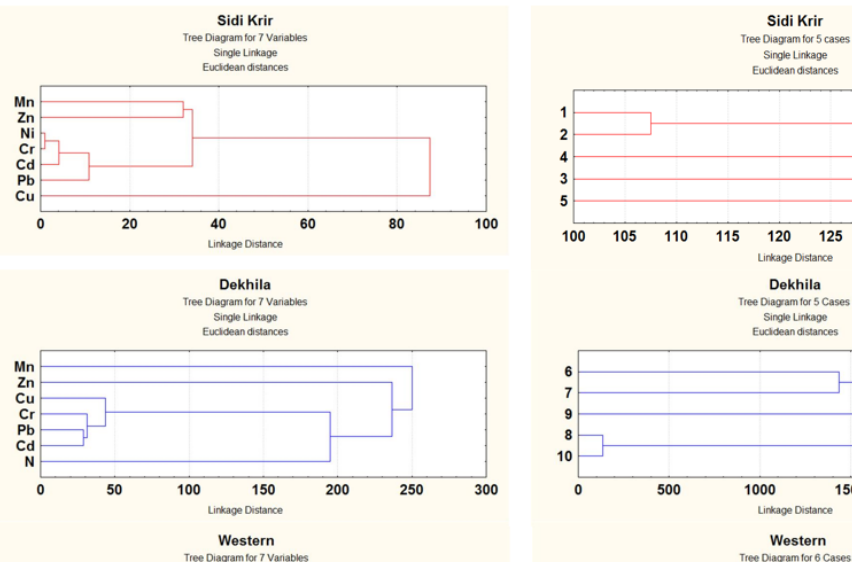

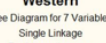
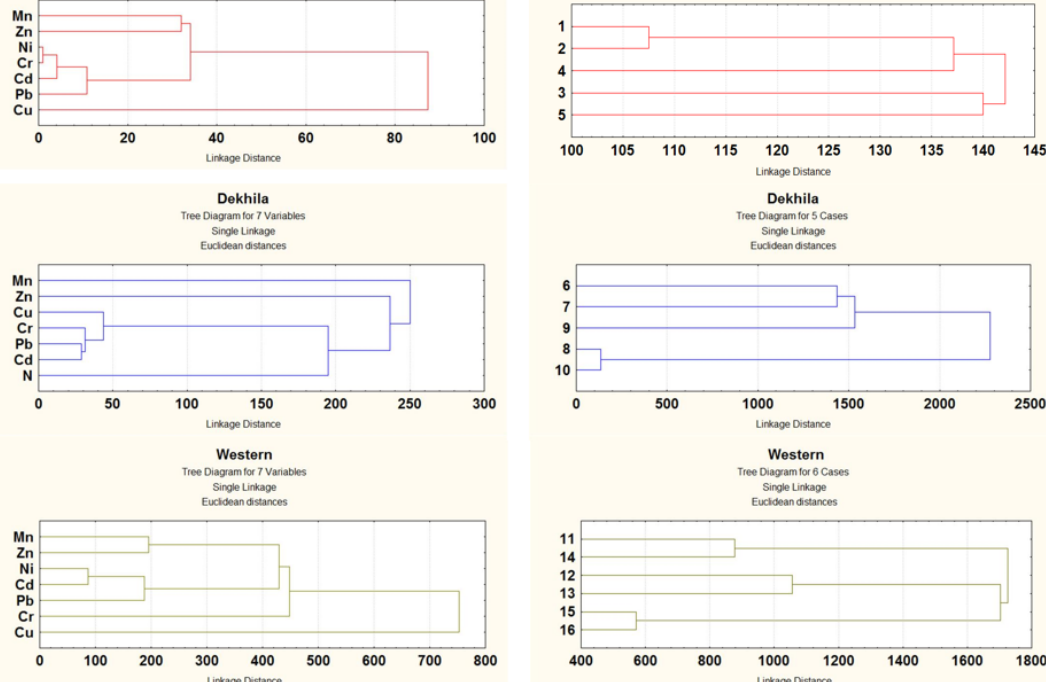

$\begin{array}{llllllllll}100 & 105 & 110 & 115 & 120 & 125 & 130 & 135 & 140 & 145\end{array}$ Dekhila

Single Linkage

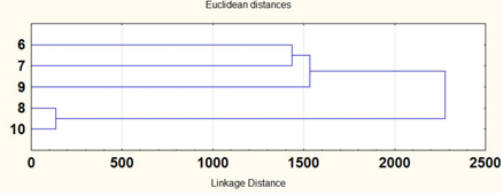

Western

ree Diagyam tor 6 Case
single Linkage
Euctidean distances

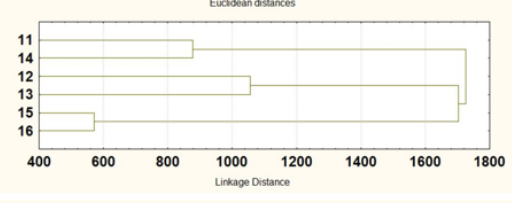

Damietta

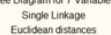

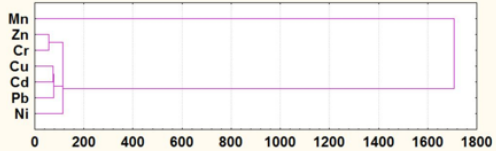

Linkage Distance

Port Said

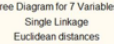

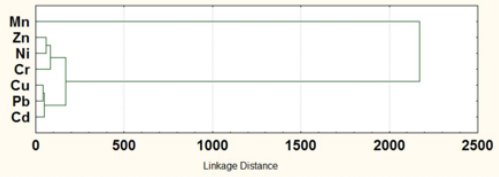

Damietta

Sinje Linkape
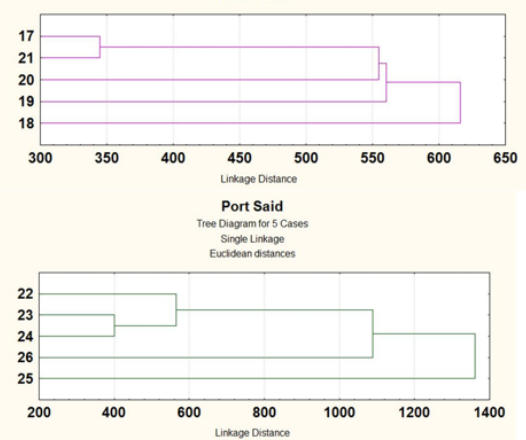

Figure 2

Tree diagram clusters analysis of studied heavy metals among themselves and with geochemical parameters along studied stations in the investigated harbors 

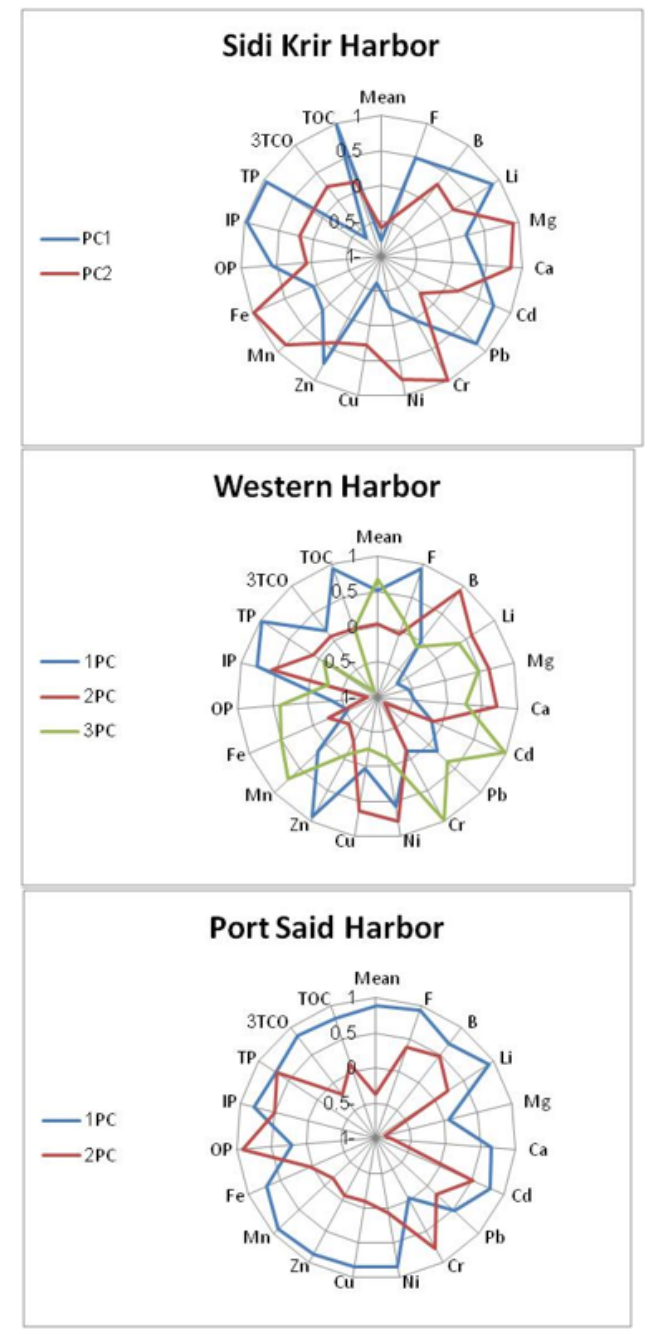

Figure 3

Factor loadings of the principle components for the studied harbors

$1 \mathrm{PC}$
$-2 \mathrm{PC}$

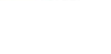

\section{Dekhila Harbor}

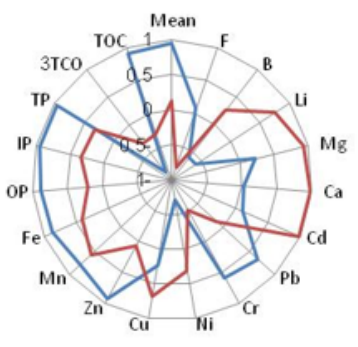

\section{Damietta Harbor}

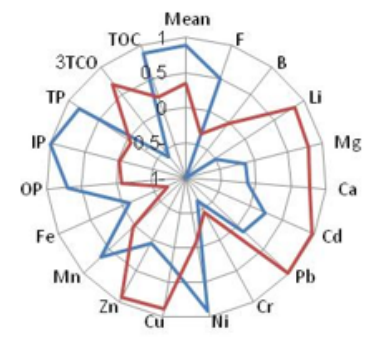

g



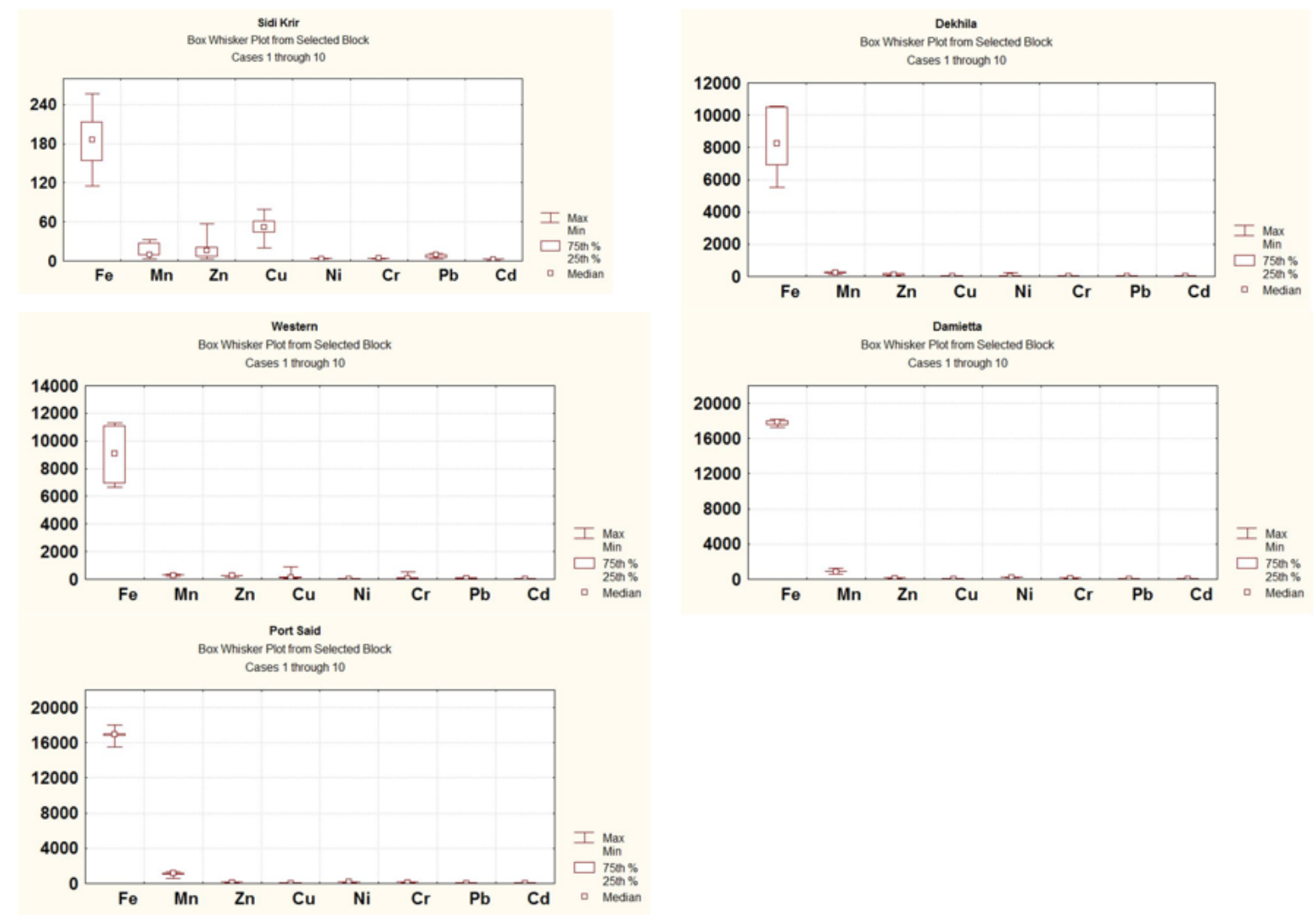

Figure 4

Box Whisker plots of the examined heavy metals in the studied harbor sediments

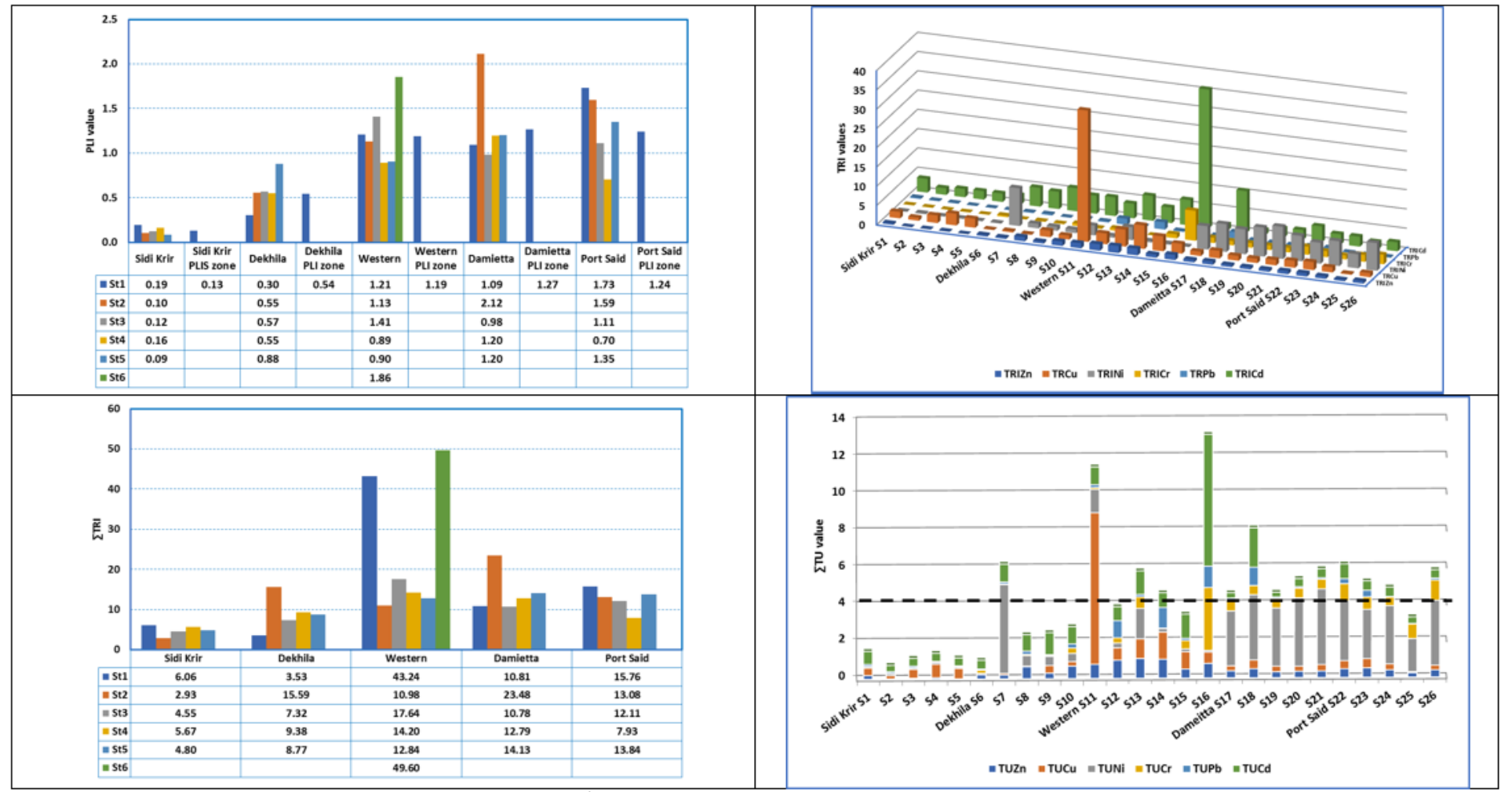

Figure 5

$P L I, T R I, \sum T R I$ and $\sum$ TUs values for all harbor zone sediments examined 
"THQAdultDerm $=$ THQAdulting $=$ THQChildDerm $=$ THQChilding
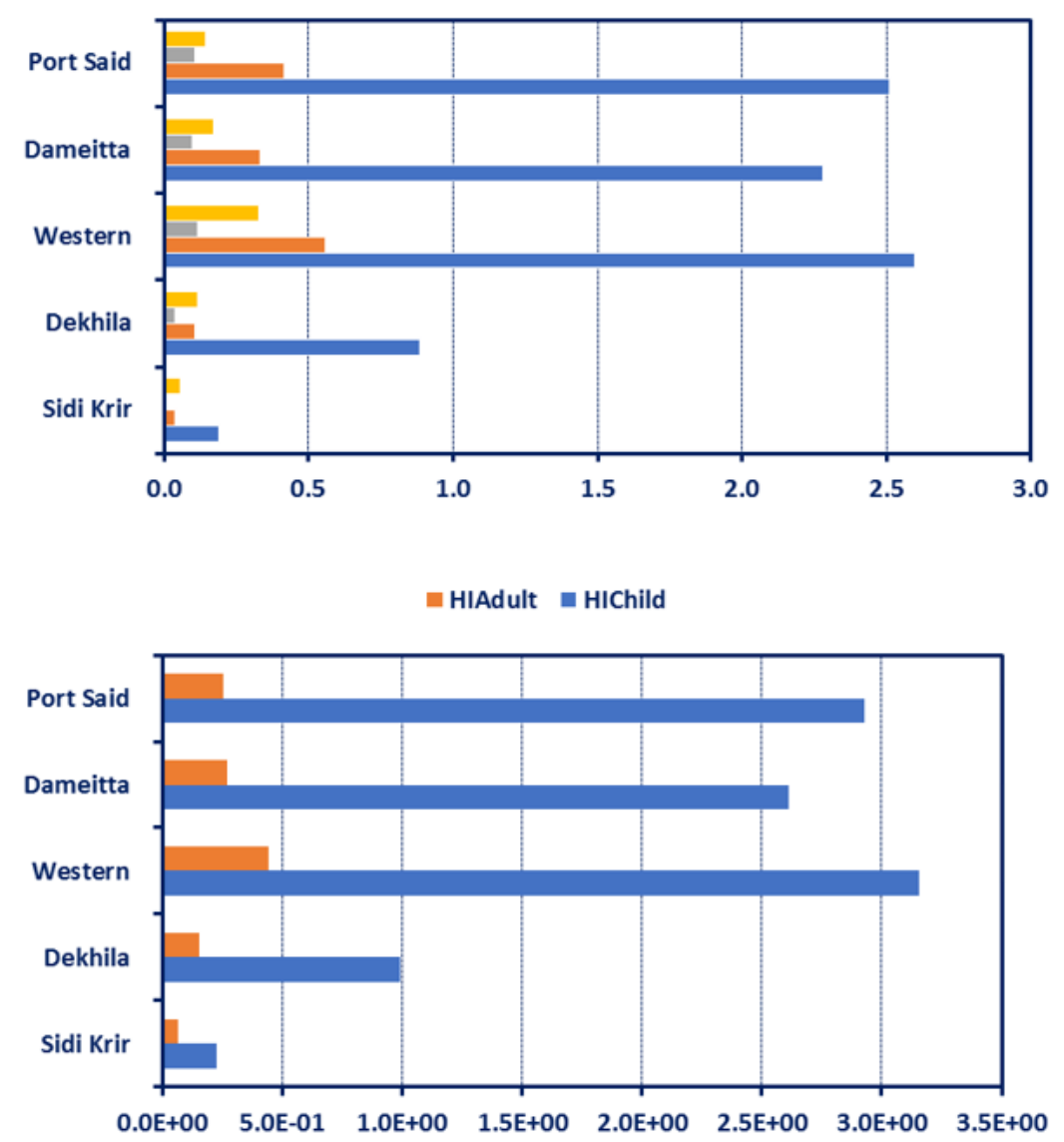

Figure 6

$T H Q$ and $H I$ for ingestion of children and adults and dermal contact with sediment 


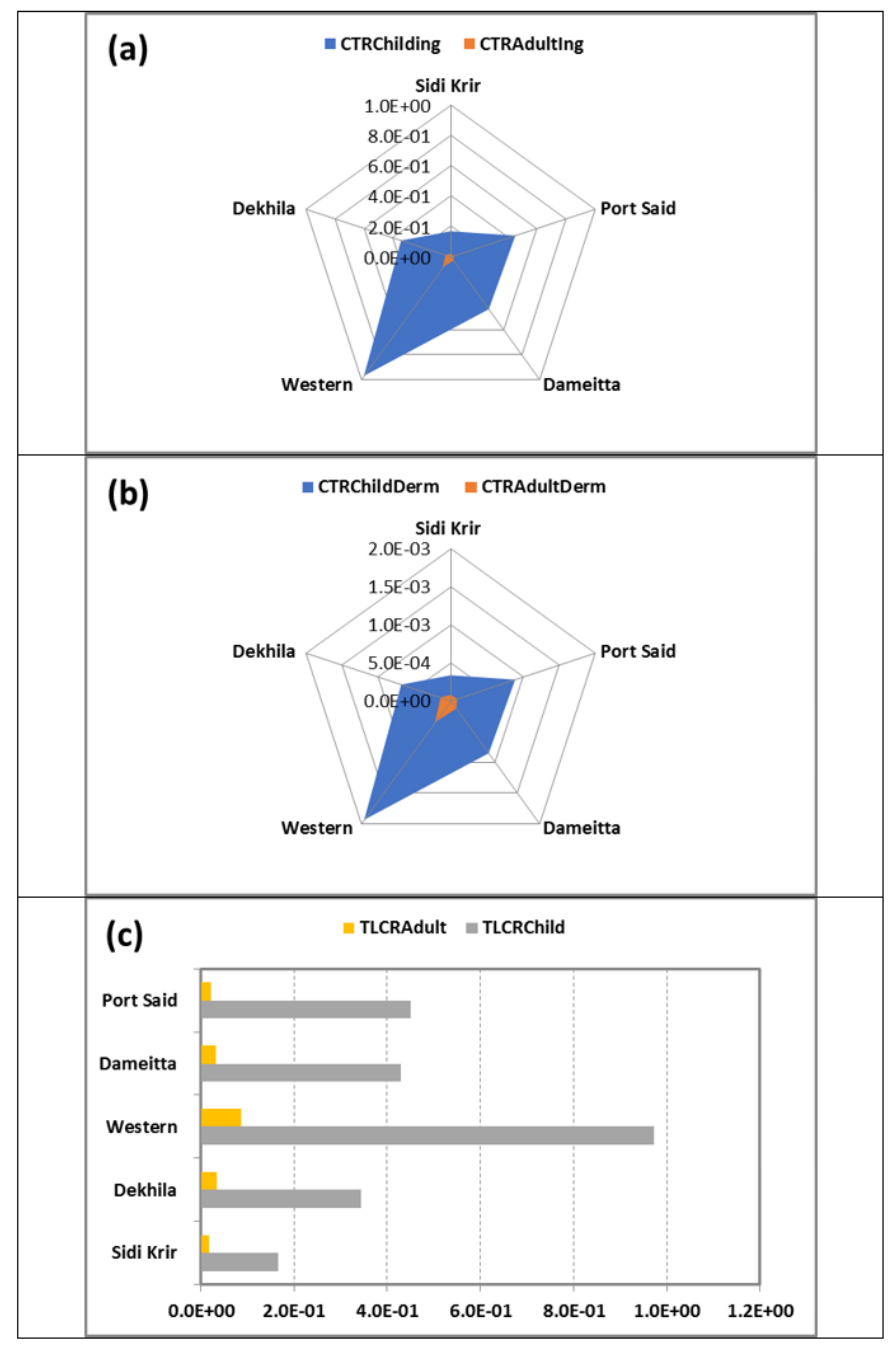

Figure 7

Cumulative target risk (a) of ingestion (b) of dermal contact (c) total lifetime cancer risk for adults and children of different heavy metals. 